\title{
FDA DISCLOSURE OF SAFETY AND EFFECTIVENESS DATA: A LEGAL AND POLICY ANALYSIS
}

A inatter of great dispute between the pharmaceutical industry and the Food and Drug Administration (FDA) is the agency's public information policy. In response to the requirements of the Freedom of Information Act (FOIA), ${ }^{1}$ the FDA in 1974 pubhshed extensive regulations ${ }^{2}$ outlining which material in its files would be subject to public disclosure. Those regulations greatly changed the agency's disclosure policy. Before they were issued, the FDA granted only about ten percent of the FOIA requests it received; 3 after they became effective over ninety-eight percent of sucl requests were approved. ${ }^{4}$ Undoubtedly, a large percentage of the increase in successful requests was due to the clarity and detail of the regulations. Nevertheless, the new procedure signified a major change by the FDA whicl it labeled a "new policy of open disclosure."

One major area affected by the regulations is the treatment of safety and effectiveness test data that must be submitted with a new

THE FOLLOWING CITATIONS WILL BE USED IN THIS COMMENT:

Clement, The Right of Submitters to Prevent Agency Disclosure of Confidential Business Information: The Reverse Freedom of Information Act Lawsuit, 55 TEX. L. REv. 587 (1977) [hereinafter cited as Clement];

F. Dworkin, Impact of Disclosure of Safety and Efficacy Data on Expenditures for Pharmaceutical Research and Development (Apr. 1978) (unpublished manuscript, Office of Planning and Evaluation, Food and Drug Administration) [hereinafter cited as Dworkin];

Pracon Incorporated, Study to Assess Impact of Releasing Safety and Effectiveness Data on the Pharmaceutical Industry's Incentives to Invest in and Conduct Research and Development Programs (Jan. 1978) (unpublished study submitted to Office of Planning and Evaluation, Food and Drug Administration) [heremafter cited as Pracon Study];

Review Panel on New Drug Regulation, United States Dep't of Health, Education and Welfare, INTERIM Report: AN Evaluation of FDA's TRAde SeCreTs aNd FreeDOM OF INFORMation Policies (Nov. 15, 1976), published in 1 INTERIM ReporTs, Review Panel on New Drug Regulation, United States Dep't of Health, Education and WelFARE (1977) [hereinafter cited as INTERIM REPORT].

l. 5 U.S.C. $\& 552$ (1976).

2. 39 Fed. Reg. 44,602 (1974) (codified in scattered sections of 21 C.F.R. (1978)).

3. See O'Keefe, The FDA's Freedom of Information Act Regulations, 30 FoOD, Drug \& CosM. L.J. 312, 313 (1975).

4. Brandenburg, Information Requests Under the FOI Act, 30 FooD, Drug \& CosM. L.J. 321,323 (1975).

5. 39 Fed. Reg. 44,602 (1974). 
drug application (NDA). ${ }^{6}$ The FDA recognizes the proprietary interest of the submitting firm in the data, ${ }^{7}$ and the regulations provide that such information is not subject to release. ${ }^{8}$ But, because of the need to inform the public of the basis for the FDA's approval of a particular NDA, the regulations permit the release of summaries of the data after the granting of an NDA. ${ }^{9}$

This disposition of the question of confidentiality of safety and effectiveness data has not ended the debate. The FDA has professed a desire to release all safety and effectiveness data in NDAs, rather than inere summaries, ${ }^{10}$ but insists that such disclosure is prohibited by the trade secrets provisions of the federal criminal code ${ }^{11}$ and the Food, Drug and Cosmetic Act. ${ }^{12}$ Industry, on the other hand, would restrict access to the data in an effort to protect the return on its imvestment in research and developinent. ${ }^{13}$ As a result of the ongoing debate and because of the feeling that such a substantive matter should be resolved by the legislative branch, the status of safety and effectiveness data has becoine a inajor concern of the proposed Drug Regulation Reform Act. ${ }^{14}$

This Comment will address both the legal and policy issues im the debate. It will be seen that the FDA's conclusion that it lacks the authority to release the safety and effectiveness data without new legislation is uncertain. This is not to say, however, that full disclosure of this data would be sound on policy grounds. In fact, the disclosure rules included in the proposed legislation are undesirable because of the likelihood of detrimental effects on research and development and the problein of drug lag. The Comment will propose an alternative scheme of disclosure policy that should accomplish the goals of full disclosure-opening up FDA decision making and reducing expensive duplicative testing - without the costs inherent in complete release of the data.

6. 21 C.F.R. \& 314.14 (1978).

7. 39 Fed. Reg. $44,602,44,612$ (1974). The preamble to the regulations states that the agency "agrees that there is a property right" in trade secrets and that the nondisclosure provisions of the regulations adequately reflect that right.

8. Id.

9. 21 C.F.R. \& 314.14(e)(2) (1978). If the existence of the NDA had been publicly acknowledged by the submitter, the agency could release summaries of selected portions prior to a final decision by the FDA on whether to allow marketing of the drug. Id. \& 314.14(d) (1978).

10. 39 Fed. Reg. 44,634, 44,642 (1974); see INTERIM REPORT 18-19.

11. 18 U.S.C. $\$ 1905$ (1976).

12. 21 U.S.C. $\$ 331(j)(1976)$.

13. See, e.g., Pendergast, Evolving Approaches to the Regulation of Prescription Drugs, 31 FOOD, DRUG \& COSM. L.J. 521, 526-27 (1976).

14. S. 2755 and H.R. 11611, 95th Cong., 2d Sess. (1978). 


\section{Overview of the Licensing Procedure for New Drugs}

Safety and effectiveness data form an essential part of the drug licensing procedure. The 1962 amendments to the Food, Drug and Cosmetic Act ${ }^{15}$ provide that no new drug can be marketed in the absence of proof to the FDA, through test data, that the substance is both safe and effective for its intended uses. ${ }^{16}$ The level of proof required by the statute is "substantial evidence," which is defined as "evidence consisting of adequate and well-controlled investigations . . . on the basis of which it could fairly and responsibly be concluded . . . that the drug will have the effect it purports or is represented to have under the conditions of use prescribed."17

This evidence is not quickly or easily developed. The process of new drug development typically begins with the screening of several chemical compounds in laboratory animals for therapeutic benefits. ${ }^{18}$ At this point, the experimenting firm selects the most promising compounds and tests various dosage levels. If the new drug is patentable (the degree of novelty that triggers the necessity for an NDA is lower than that required to establish a patent ${ }^{19}$ ), patent apphcations for the most promising and related compounds are usually filed at this stage. This is done to ensure that the firm does not invest many years and tens of millions of dollars in the development of a new drug only to have its effort preeinpted by another firm's patent.

Early patenting benefits all researching firms by providing notice of competitors' efforts and allowing for the avoidance of much wasteful, duphcative testing, thereby encouraging efficient allocation of the

15. 21 U.S.C. \& 355 (1976).

16. Id. \&355(a).

17. Id. $\& 355(\mathrm{~d})$.

18. Review Panel on New Drug Regulation, U.S. Dep't of Health, Education \& Welfare, Final Report 19 (1977). See also Pines, A Primer on New Drug Development, FDA CONSUMER, Feb. 1974, at 12.

19. The definition of a "new drug" is found at 21 U.S.C. \& 321(p) (1976):

(1) Any drug . . . the composition of which is such that such drug is not generally recognized, among experts qualified by scientific training and experience to evaluate the safety and effectiveness of drugs, as safe and effective for use under the conditions prescribed, recommended, or suggested in the labeling thereof . . . .

(2) Any drug. . . the composition of which is such that such drug, as a result of investigations to determine its safety and effectiveness for use under such conditions, has become so recognized, but which has not, otherwise than in such investigations, been used to a material extent or for a material time under such conditions.

The key in determining the need for an NDA, therefore, is whether the compound is generally recognized as safe and effective under the proposed conditions; not, as it is for the purpose of a patent, whether the compound is novel. J. MASHAW \& R. MERRILL, INTRODUCTION TO THE American Public Law System CASes and Materials 463 (1975). The patent requireinent of "non-obviousness" makes specific dosage forms, coinpounds discussed in published scientific hiterature and those found in nature not patentable. INTERIM REPORT 30. 
limited resources available for drug research. ${ }^{20}$ Although there are no statistics on the percentage of recently granted or pending NDAs that are patented, the FDA has indicated that the percentage is quite high. ${ }^{21}$ Between 1962 and 1975 only $29.7 \%$ of all new drug sales were of nonpatented drugs. ${ }^{22}$ Some of those sales undoubtedly consisted of patented drugs whose patent had expired. Thus, it seems fair to conclude that the great majority of new drugs, and certainly the most important, are patented.

Before huinan testing of a new drug can begin, the developer inust file with the FDA a "Notice of Claimed Investigational Exemption for a New Drug" (IND). In this document the developer must disclose the composition of the new drug, its manufacturing fornula, the results of all animal tests relating to the drug's therapeutic promise and a detailed description of the proposed human testing (the protocol). ${ }^{23}$ If the FDA does not contest the IND within 30 days, it becomes effective and human testing can begin. ${ }^{24}$

The testing of experimental drugs on human subjects is carried out in three stages. In Phase I the drug is given to a small number of voluntary healthy subjects, usually less than ten, to determine whether the drug is reasonably safe for human use and to ascertain the appropriate dosage level and forn. After this is conpleted, the human testing enters Phase II, which consists of trials on a larger, but still very limited, population aimed at determining the effectiveness of the drug. If these results are satisfactory, the drug will enter the final and most extensive stage of testing. Phase III consists of large-scale, carefully controlled clinical trials. Hundreds of patients are usually involved in this final effort to assess the safety, effectiveness and preferred dosage of the new drug. ${ }^{25}$

When all of the testing has been completed, the developer subinits the test data to the FDA. This information, combined with that in the IND, is the NDA, which often consists of thousands of pages. The FDA is required by statute to act on an NDA within 180 days. ${ }^{26}$ In practice, however, this rarely occurs. In most cases, the agency and

20. See Kitch, The Nature and Function of the Patent System, 20 J. LAw \& EcoN. 265 (1977).

21. INTERIM REPORT 30 n. 98 .

22. Dworkin 6. The term "new drugs" is defined as all single chemical entities, synthesized drugs, salts and esters introduced in the United States for the first time in the period under study, 1962-1975. Id.

23. 21 C.F.R. $\$ 312$ (1978); Pines, supra note 18, at 12.

24. 21 C.F.R. $\$ 312.1$ (1978).

25. Final RePORT, supra note 18, at 20; Pines, supra note 18, at 12-14.

26. 21 U.S.C. $\$ 355$ (c) (1976). 
firm either agree to an extension of time (as permitted by statute ${ }^{27}$ ), or the FDA declares the NDA incoinplete and seeks additional information. ${ }^{28}$

\section{Present Treatment of Safety and Effectiveness Data}

The FDA's disclosure policy regarding safety and effectiveness data has undergone great evolution. Prior to the enactment of the Freedom of Information Act, ${ }^{29}$ the agency viewed all data in an NDA as strictly confidential. ${ }^{30}$ It was not until 1972, six years after the enactinent of the FOIA heralded the new era of open disclosure, that the FDA attempted in proposed regulations to delineate what constituted a trade secret in an effort to clarify that exemption from the disclosure requirements of the FOIA. ${ }^{31}$ The agency acted under these proposals for two years, until the extensive "Public Information Regulations" were issued in $1974 .^{32}$

These regulations purport to release all of the safety and effectiveness data that the law permits. ${ }^{33}$ A distinction is drawn between antibiotics and other human drugs. Since petitions to market antibiotics result in publicly printed regulations rather than private licenses, ${ }^{34}$ the

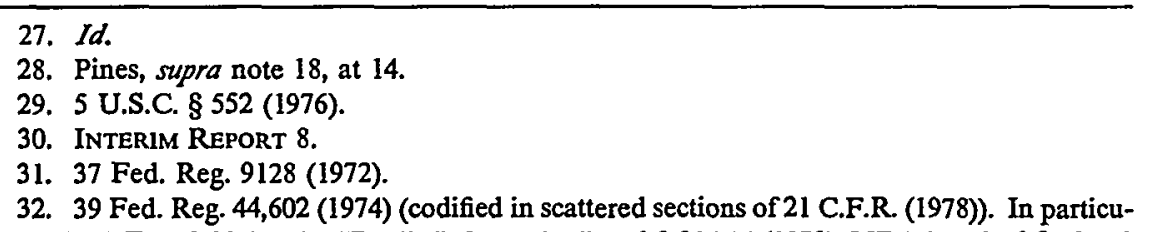
lar, see 21 C.F.R. $\$ 20$ (1978) ("Public Information"), id. $\$ 314.14$ (1978) (NDAs) and id. $\$ 431.71$ (1978) (antibiotic drugs).

One sarcastic reviewer of FDA policy wrote:

Tlue regulations, like the Savior, arrived in final form on Christmas Eve, when a new babe of some 15 pages was born-preambled by 307 numbered paragraphs covering 40 pages, all swaddled in the Federal Register.

The new child, first proposed in May of 1972, was nurtured by almost 700 comment letters sent to its father-the FDA, or PBH, or both-and gestated for $21 / 2$ years in the womb in Rockville.

While its final coming has been recent, the preamble informs ns that the regulations lave been working miracles for over two years. And, indeed, the preamble provided 60 days for further comment on new matters and promised consideration of such comments and possible changes yet to come. So, while the regulations are now final, they are not quite final. But they are probably final enough. That is, unless you want to accept the cordial invitation of the Commissioner to "institute legal action in the courts to contest their validity" and, if successful, have thein declared an abortion.

O'Keefe, supra note 3, at 313 .

33. See 39 Fed. Reg. 44,602, 44,635 (1974).

The Commissioner agrees that public policy supports release of all safety and effectiveness data, but points out that present statutory law, 18 U.S.C. [\$] 1905 and 21 U.S.C. [\$]] 331(j), prohibits sucl release . . . . The Commissioner has no authority to institute sucl Id. a system [of release] without statutory authorization from Congress.

34. 21 U.S.C. $\$ 357$ (1976); 21 C.F.R. $\$ 431$ (1978). 
FDA concluded that safety and effectiveness data relating to antibiotics could not be considered a trade secret or confidential commercial information $^{35}$ and is thus subject to release. Developers of new antibiotics must therefore rely on patents to protect their research investment.

For all other new drugs intended for human use, permission to 1narket is given in the form of a private license. In view of the large mvestment necessary to obtam such a license and the possibility of competitive harm to the submitting firm resulting froun the release of safety and effectiveness data, ${ }^{36}$ the agency determined that such inforination was entitled to protection. But that protection is not absolute. If the applicant has made the information public, ${ }^{37}$ or if the drug has been disapproved, withdrawn from the market, found not to be "new," or the application abandoned, the safety and effectiveness data is subject to release "unless extraordinary circumstances are shown."38

Thus, safety and effectiveness data for approved and pending NDAs is protected unless disclosed by the developer. However, the FDA does recognize the public's need for information regarding the basis of the agency's decision to allow inarketing of a new drug. The agency therefore releases summaries of the safety and effectiveness data following approval of an NDA. ${ }^{39}$ For drugs approved after July 1, 1975 , the summary unay be compiled by the submitter or the agency. The summary need not imclude the protocol for the study if it is distinguishable from other protocols and if its unique design gives the submitter a competitive advantage over other firms that are unaware of the

35. 21 C.F.R. \$ 431.71(e)(1) (1978); 39 Fed. Reg. 44,631-32 (1974). This reasoning is rejected by one commentator who presumably feels that even the antibiotic test data can be misappropriated to the coinpetitive detriment of the developing coinpany. Whyte, Drug Company Concerns and Opportunities-How We Will Cope, 30 FOOD, DRUG \& CoSM. L.J. 338, 340 (1975).

36. Even if the drug is protected by a U.S. patent, a coinpetitor could use the data to inarket the drug in foreign countries where the original developer does not have a patent. In some countries, drugs are not patentable. The United States accounts for only about $18 \%$ of all world drug sales, and this market share is declining. Therefore, release of safety and effectiveness data could result in significant competitive harm to investment in research and development of the new drug, regardless of whether the drug is protected by a U.S. patent. See Dworkin Attachment B, at 2.

37. See 21 C.F.R. $\$ 20.81$ (a) (1978).

38. Id. § 314.14(f); see INTERIM REPORT 13-14. The preamble to the 1974 regulations offers two examples of such "extraordinary circumstances." If a conpany is already marketing a drug overseas and seeks an IND for marketing in this country, but the company later has that IND terminated, the summary of data in the terminated IND could contain information that would imjure the submitter's position in the preexisting foreign inarket if made available to competitors. If the company could show the likelihood of such damage in "concrete terms," the agency might invoke the "extraordinary circumstances" exeinption. Another situation where the agency might not release otherwise disclosable summaries would be when such a release would directly harm the conıpetitive status of another, pending IND or NDA. 39 Fed. Reg. 44,602, 44,633, 44,638 (1974).

39. 21 C.F.R. $\$ 314.14(\mathrm{e})(2)$ (1978). See note 9 supra. 
particular test procedures. ${ }^{40}$

It should be noted that even without new legislation, the FDA's public information policy has continued to evolve. In the past, the FDA has treated the very existence of an $\mathrm{IND}^{41}$ or an $\mathrm{NDA}^{42}$ as a trade secret not subject to disclosure on the theory that the applicant has a coinpetitive interest in the inaintenance of secrecy with respect to the direction of new drug research. The FDA has recently proposed changes in the disclosure regulations to permit the agency to reveal the existence, but not the content, of the notices and apphications. This change, it feels, will provide "the pubhic greater information about the agency's workload and progress in reviewing those applications." 43

Neither the present nor the proposed agency regulations, however, allow release of safety and effectiveness data, even in summary form, before the FDA has acted on a pending NDA, with the exception of those instances where the submitter has already made the information public. Consequently, in inost cases, the public is effectively precluded from offering any input whatsoever into the agency's decision regarding whether to allow marketing of a new drug.

\section{Can the FDA Release the Data Under Present Law?}

In evaluating the FDA's contention that it is legally prohibited from releasing safety and effectiveness data (beyond the summaries for approved drugs), it will be helpful to pose a scenario in which the FDA favors release and then examine the theories under which a drug developer might atteinpt to prevent such action. The best way for the agency to estabhish a procedure for the release of the data would be through the promulgation of appropriate regulations under both the FOIA and 5 U.S.C. $\S 301.44$ The latter statute, a general housekeeping provision, gives the head of each executive department the authority to promulgate regulations for "the custody, use, and preservation of its records, papers, and property ... . [but] does not authorize withholding information from the public or limiting the availability of records to the

40. 21 C.F.R. $\$ \$ 20.61,314.14(e)(2)$ (1978). This, of course, allows a company to protect its investment in new research techniques as well as the chemical entities themselves.

41. Id. $\$ 312.5$.

42. Id. $\$ 314.14(\mathrm{~b})$.

43. 43 Fed. Reg. $12,869,12,870$ (1978). The real value of this new procedure is that, like the patent system, it will identify for the public and the company's competitors the areas in which research is being conducted. This is one of the major criticisms of the present policy, and the problem is addressed in the proposed legislation. See text accompanying notes 189-98 infra.

44. Section 301 was originally enacted in the Act of Sept. 6, 1966, Pub. L. No. 89-554, § 301, 80 Stat. 378. 
public." 45 By basing the regulations on both statutes, the FDA would protect itself from the argument that the FOIA cannot be relied upon for authorization of the release of information that falls within its exemptions. ${ }^{46}$ By its specific language, the FOIA "does not apply to matters" that fall within its nine exemptions. ${ }^{47}$ Thus, it might be argued that because safety and effectiveness data fall within the trade secrets exemption and the FOIA does not apply to that material, regulations authorizing its release cannot be based on the FOIA. This position has been taken by several courts. ${ }^{48}$ For this reason, regulations authorizing the release of material falling within the exemptions should not be based on the FOIA alone.

Section 301 provides an additional statutory basis for the regulations. The legislative history ${ }^{49}$ shows that section 301 does not permit the proinulgation of regulations providing for the release of information if that release is prohibited by another statute. ${ }^{50}$ But the FOIA is not such a statute. Its exemptions are discretionary rather than mandatory. ${ }^{51}$ The Supreme Court has stated that the exemptions reflect "congressional determination of the types of information that the Executive Branch must have the option to keep confidential, if it so chooses." 52 There is abundant support for this position in the legislative history of the Act. One Senate report, for example, states that "[the exeinptions] are only permissive. They merely mark the outer limits of information that may be withheld when the agency makes a specific affirmative determination that the public interest and the specific circumstances dictate . . . that the information should be withheld."53

45. 5 U.S.C $\$ 301$ (1976).

46. The submitters will claim that since the information falls within exemption 4 (the "trade secrets" exemption) of the FOIA, the FDA either cannot or should not release it. See note 76 infra and text accompanying notes 76-110 infra.

47. 5 U.S.C. \& 552(b) (1976).

48. See NLRB v. Sears, Roebuck \& Co., 421 U.S. 132, $147-48$ (1975) ("if the memoranda do fall within one of the Act's exempt categories, our inquiry is at an end, for the Act 'does not apply' to such documents"); Charles River Park "A", Inc. v. Department of HUD, 519 F.2d 935, 942 (D.C. Cir. 1975); Parkridge Hosp., Inc. v. Blue Cross \& Blue Shield, 430 F. Supp. 1093, 1097 (E.D. Tenn. 1977). One commentator has criticized this approach on the theory that such a restriction on FOIA regulations converts the permissive exemptions into mandatory ones. Clement 620.

49. See text accompanying notes $152-57$ infra.

50. E.g., 18 U.S.C. \& 1905 (1976) (Trade Secrets Act); 21 U.S.C. § 331(j) (1976) (confidentiality provision of Food, Drug and Cosmetic Act). (For a discussion of whether release of the safety and effectiveness data under regulations issued as suggested above would violate those statutes, see text accompanying notes 113-75 infra.) In Chrysler Corp. v. Brown, the Supreme Court apparently endorsed this view of section 301. 99 S. Ct. 1705, $1722 \mathrm{n} .40$ (1979).

51. Chrysler Corp. v. Brown, 99 S. Ct. 1705 (1979).

52. EPA v. Mink, 410 U.S. 73, 80 (1973) (emphasis added).

53. S. REP. No. 854, 93d Cong., 2d Sess. 6 (1974) (einphasis in original); see H.R. REP. No. 876, 93d Cong., 2d Sess. 4 (1974); Clement 598-603. Although these congressional reports as well 


\section{A. Reverse FOIA Suit-Subject Matter Jurisdiction and the Standard of Review.}

If the FDA were to issue regulations authorizing the disclosure of safety and effectiveness data, the submitters of that data would likely seek injunctive relief in federal court througl a "reverse FOIA suit." 54 For years there was disagreement about the proper mode of subject matter jurisdiction in sucl cases. Althougli some courts have based jurisdiction on the FOIA itself, ${ }^{55}$ most have lield that the Act "is a disclosure statute and does not by its explicit terms confer jurisdiction over an action seeking to prevent disclosure." of jurisdiction is the Trade Secrets Act, ${ }^{57}$ a criminal statute. While some courts liave avoided this issue, ${ }^{58}$ most agree that simce the criminal penalties in the statute appear adequate, ${ }^{59}$ no civil cause of action lies. ${ }^{60}$ Anotlier possible avenue to jurisdiction-the Administrative

as others that state that the exemptions are discretionary are not the reports of the original act itself, but rather of amendments to the FOIA and related legislation, they may be appropriately used as authority. Holliday v. Ketchum, MacLeod \& Grove, Inc., 584 F.2d 1221, 1229 (3d Cir. 1978).

Cases holding that the exemptions are permissive are legion. See, e.g., Sears, Roebuck \& Co. v. Eckerd, 575 F.2d 1197 (7th Cir. 1978); General Dynamics Corp. v. Marshall, 572 F.2d 1211 (8th Cir. 1978), vacated and remanded, 99 S. Ct. 2024 (1979); Chrysler Corp. v. Schlesinger, 565 F.2d 1172 (3d Cir. 1977), vacated and remanded sub nom. Chrysler Corp. v. Brown, 99 S. Ct. 1705 (1979); Pennzoil Co. v. FPC, 534 F.2d 627 (5th Cir. 1976); Charles River Park “A”, Inc. v. Department of HUD, 519 F.2d 935 (D.C. Cir. 1975).

54. See generally Note, Developments Under the Freedom of Information Act-1977, 1978 Duke L.J. 189, 204-10; Note, Protection from Government Disclosure-The Reverse-FOIA Suit, 1976 DUKE L.J. 330.

55. See, e.g., National Parks \& Conservation Ass'n v. Morton, 498 F.2d 765 (D.C. Cir. 1974); McCoy v. Weinberger, 386 F. Supp. 504 (W.D. Ky. 1974).

56. Parkridge Hosp., Inc. v. Blue Cross \& Blue Shield, 430 F. Supp. 1093, 1095 (E.D. Tenn. 1977); see Sears, Roebuck \& Co. v. Eckerd, 575 F.2d 1197, 1203 (7th Cir. 1978) (in the FOIA "only requesters [of information] have been given a cause of action by the Congress").

57. 18 U.S.C. $\$ 1905$ (1976).

58. In Planning Research Corp. v. FPC, 555 F.2d 970 (D.C. Cir. 1977), the eourt wrote "we express no opinion on whether $\$ 1905$ [the Trade Secrets Act] may constitute an imdependent basis of jurisdiction for at least some 'reverse-FOIA' suits." Id. at 977 n.12; see Charles River Park "A", Inc. v. Department of HUD, 519 F.2d 935, 941 (D.C. Cir. 1975).

59. This statute provides for a fine of up to $\$ 1000$, or imprisonment for up to one year, or both, and automatic removal from office for any government employee who violates it.

60. The court in Chrysler Corp. v. Schlesinger, 565 F.2d 1172 (3d Cir. 1977), vacated and remanded sub nom. Chrysler Corp. v. Brown, 99 S. Ct. 1705 (1979), wrote:

[We] . . . reject the proposition that $\S 1905$ [the Trade Secrets Act] . . . serve[s] as a predicate for a private civil cause of action. Recent prononncements of the Supreme Court have severely limited the circumstances in which a federal court nay imply a private cause of action from a federal statute . . . . The adequacy of these penalties would seem to assure the achievement of the Congressional objectives underlymg $\S 1905$.

565 F.2d at 1188 (footnotes onnitted); the Supreme Court agreed with this analysis, 99 S. Ct. at 1725. See Sears, Roebuck \& Co. v. Eckerd, 575 F.2d 1197 (7th Cir. 1978); General Dynamics Corp. v. Marshall, 572 F.2d 1211 (8th Cir. 1978), vacated and remanded, 99 S. Ct. 2024 (1979). But 
Procedure Act (APA) ${ }^{61}$-was blocked by the Supreme Court when it ruled in Califano v. Sanders ${ }^{62}$ that section 10 of the APA does not grant subject matter jurisdiction independent of other grounds.

Since Sanders, there has been general agreement that reverseFOIA suits may be heard under general federal question jurisdiction. ${ }^{63}$ Because such actions are designed to prevent disclosure by a federal agency or officer, there is no requirement of a $\$ 10,000$ amount in controversy. ${ }^{64}$. Some courts, recognizing the policy behind these exemptions, ${ }^{65}$ have argued that the FOIA poses a federal question within the court's equitable jurisdiction. ${ }^{66}$ Other courts have ruled more generally that "federal question jurisdiction may be sustained whether the action is viewed as 'arising under' [the] FOIA itself or whether it is conceived inore broadly as the assertion of a private party's right 'to be free from agency action which adversely affects him and is not authorized by federal law." "67 Thus, it is clear that the submitters will not find subject inatter jurisdiction an obstacle to having a court hear their challenge to the FDA disclosure regulations.

Next, the court inust determine the proper standard of review. This is a two-step process. If the FDA were to contest whether safety and effectiveness data falls within the trade secrets exemption of the FOIA, then the court would be required to conduct a full review on this issue. $^{68}$ It is unlikely, however, that the agency would dispute this point. Rather, it would argue that although the data does fall within an exeinption, the agency has discretionary authority to disclose such information and the decision to release can be set aside only if it is found to constitute an abuse of discretion. This position, adopting the stan-

see Westinghouse Elec. Corp. v. Schlesinger, 542 F.2d 1190 (4th Cir. 1976), cert. denied, 431 U.S. 924 (1977).

61. 5 U.S.C. $\$ \$ 701-706$ (1976). Cases finding jurisdiction under the APA include Charles River Park “A”, Inc. v. Department of HUD, 519 F.2d 935 (D.C. Cir. 1975); Parkridge Hosp., lnc. v. Blue Cross \& Blue Shield, 430 F. Supp. 1093 (E.D. Tenn. 1977); Metropolitan Life Ins. Co. v. Usery, 426 F. Supp. 150 (D.D.C. 1976), cert. denied, 431 U.S. 924 (1977).

62. 430 U.S. 99 (1977).

63. 28 U.S.C. $\$ 1331$ (1976).

64. 28 U.S.C. $\$ 1331$ (1976).

65. See text accounpanying notes 52-53 supra.

66. See Sears, Roebuck \& Co. v. GSA, 553 F.2d 1378 (D.C. Cir.), cert. denied, 434 U.S. 826 (1977); Westinghouse Elec. Corp. v. Schlesinger, 542 F.2d 1190 (4th Cir. 1976), cert. denied, 431 U.S. 924 (1977); Theriault v. United States, 503 F.2d 390 (9th Cir. 1974).

67. Planning Researcl Corp. v. FPC, 555 F.2d 970, 977 (D.C. Cir. 1977) (quoting 1976 Note, supra note 54, at 352); see 1978 Note, supra note 54, at 206-10.

68. Westinghouse Elec. Corp. v. Schlesinger, 542 F.2d 1190, 1208 n.57 (4th Cir. 1976), cert. denied, 431 U.S. 924 (1977); Charles River Park "A", Inc. v. Department of HUD, 519 F.2d 935, 940-41 n.4 (D.C. Cir. 1975). 
dard of the APA, ${ }^{69}$ has been accepted by a majority of the courts. ${ }^{70}$

There is some authority for the proposition that if the submitter of information were to brimg suit for a declaratory judgment prior to any release of data by the agency, then the standard of review would not be limited to the APA "abuse of discretion" test. ${ }^{71}$ Simce the agency has not acted, it is argued, there is no act to which agency discretion can be applied. This argument ignores the limitations of declaratory judgment procedure: it "will not be used to pre-empt and prejudge issues that are committed for initial decision to an administrative body or special tribunal any inore than it will be used as a substitute for statutory methods of review." Declaratory Judgment Act to permit a federal court to conduct a trial de novo in reverse FOIA cases would transfer primiary decisional responsibility for agency disclosures from the administrative agencies to the federal courts." 73 Thus, it appears that the burden will be on the submitters of the data to show that release would involve an abuse of agency discretion.

\section{B. Arguments of the Submitters to Prevent Release of the Data by the FDA.}

The subinitters of safety and effectiveness data might rely on several theories emanatimg from the FOIA, the Trade Secrets Act $^{74}$ and the confidentiality provision of the Food, Drug and Cosmetic Act $^{75}$ in an effort to prevent FDA disclosure of the data. Before the submitters can advance the intricacies of these theories, however, they must prevail on the threshold issue of whether the safety and effectiveness data falls within the protection of exemption 4 of the FOIA. ${ }^{76}$ That provision covers two kinds of material: first, trade secrets and, second, "imformation which is (a) commercial or financial, (b) obtamed from a person, and (c) privileged or confidential. The exemption given by the

69. 5 U.S.C. § 702 (1976).

70. See, e.g., Chrysler Corp. v. Brown, 99 S. Ct. 1705 (1979); Pennzoil Co. v. FPC, 534 F.2d 627 (5th Cir. 1976).

71. See Sears, Roebuck \& Co. v. GSA, 553 F.2d 1378, 1381 (D.C. Cir.), cert. denied, 434 U.S. 826 (1977).

72. Public Serv. Comm'n v. Wycoff Co., 344 U.S. 237, 246 (1952).

73. Chrysler Corp. v. Schlesinger, 565 F.2d 1172, 1191 (3d Cir. 1977), vacated and remanded sub nom. Chrysler Corp. v. Brown, 99 S. Ct. 1705 (1979).

74. 18 U.S.C. \& 1905 (1976).

75. 21 U.S.C. $\S 331(j)(1976)$.

76. 5 U.S.C. \& 552(b) (1976) provides in pertinent part:

This section does not apply to matters that are-

(4) trade secrets and commercial or financial information obtained from a person and privileged or confidential. 
Congress does not apply to information which does not satisfy the three requirements stated im the statute." 77

Almost all of the litigation over this exemption has dealt with the second part, while very few cases have construed the term "trade secrets." However, the confidentiality provision of the Food, Drug and Cosmetic Act refers to "any method or process which as a trade secret is entitled to protection,"78 and therefore it is necessary to determine whether safety and effectiveness data constitutes a trade secret.

Nowhere is the scope of the term "trade secret" definitively delineated for purposes of the FOIA. The legislative history contams no statement of congressional imtent with respect to the coverage of the term in this context, nor has the Supreme Court ruled on the question. One definition, that of the Restatement of Torts, has received a great deal of attention. It states that a trade secret is "any formula, pattern, device or compilation of information which is used in one's business, and gives him an opportunity to obtain an advantage over competitors who do not know or use it."79 The Suprene Court, citing this definition as one "widely relied-upon," 80 applied it in a case imvolving a patent problem. Several lower federal courts have used the Restatement definition in exeinption 4 cases, ${ }^{81}$ but that application has been mechanical and the courts have offered no explanation of the appropriateness of this definition as applied to the FOrA. Finally, the FDA itself relied upon the Restatement definition in the preamble to the Public Information Regulations. ${ }^{82}$

An alternate definition of the term "trade secret" is found in Consumers Union of the United States, Inc. v. Veterans Administration. ${ }^{83}$ In its discussion of the scope of the term "trade secret" in the context of disclosure prohibited by the Trade Secret Act, ${ }^{84}$ the court stated that it was aware of only one case-law definition: "an unpatented, secret, commercially valuable plan, appliance, formula, or process, which is used for the making, preparing, compounding, treating, or processing

77. Consumers Union of the United States, Iuc. v. Veterans Administration, 301 F. Supp. 796, 802 (S.D.N.Y. 1969), appeal dismissed as moot, 436 F.2d 1363 (2d Cir. 1971); accord, Getman v. NLRB, 450 F.2d 670, 673 (D.C. Cir. 1971); see Kuersteiner \& Herbach, The Freedom of Information Act: An Examination of the Commercial or Financial Exemption, 16 SANTA CLARA L. REv. 193, 200 (1976).

78. 21 U.S.C. $\$ 331(\mathrm{j})$ (1976). See text accompanying notes $165-75$ infra.

79. RESTATEMENT OF TORTS § 757, comment b (1939).

80. Kewanee Oil Co. v. Bicron Corp., 416 U.S. 470,474 (1974).

81. See, e.g., Union Oil Co. v. FPC, 542 F.2d 1036, 1044 (9th Cir. 1976); Chevron Chem. Co. v. Costle, 443 F. Supp. 1024, $1031-32$ (N.D. Cal. 1978).

82. 39 Fed. Reg. $44,602,44,612$ (1974).

83. 301 F. Supp. 796 (S.D.N.Y. 1969), appeal dismissed as moot, 436 F.2d 1363 (2d Cir. 1971).

84. 18 U.S.C. § 1905 (1976). 
of articles or materials which are trade commodities."85

Clearly, the Restatement definition is much broader than the one set forth in Consumers Union. Although both definitions require certain fundamental elements of trade secrecy-that the information be secret, commercially valuable, used in one's busmess and not generally known within the industry-the Restatement definition covers any kind of information that gives the possessor of the secret a commercial advantage. The more limited Consumers Union definition, on the other hand, protects only certaim types of information (a "plan, apphance, formula, or process") used for certain specified purposes ("the making, preparing, compounding, treating, or processing . . . of trade commodities").

The arguments in favor of adopting the Restatement definition for FOIA purposes are centered around its comprehensiveness and its widespread usage. First, the FOIA exemptions, regardless of whether they' are viewed as mandatory or permissive, ${ }^{86}$ are indicative of congressional concern for the protection of submitters' information. ${ }^{87}$ The House report on the original FOIA states the purpose of the fourth exemption:

This exemption would assure the confidentiality of information obtained by the Government through questionnaires or through material submitted ..... It exempts such material if it would not customarily' be made public by the person from whom it was obtained by the Government. The exemption would include . . . scientific or manufacturing processes or developments . . . . It would also mclude information which is given to an agency im confidence, simce a citizen must be able to confide in his Government. 88

The exemption does, therefore, protect submitters of financial or commercial data to government agencies "from the competitive disadvantages which would result from its publication." 89 The Restatement definition, covering any kind of trade secret information that gives its holder a competitive advantage, conforms closely to the purpose of the

85. 301 F. Supp. at 801 (quoting United States ex rel. Norwegian Nitrogen Prod. Co. v. United States Tariff Comm'n, 6 F.2d 491, 495 (D.C. Cir. 1925), rev'd on other grounds, 274 U.S. 106 (1927)).

86. See text accompanying notes 47-53 supra.

87. Clement 593.

88. H.R. REP. No. 1497, 89th Cong., 2d Sess. 10, reprinted in [1966] U.S. CodE CoNG. \& AD NEws 2418, 2423.

This is not to say that an agency's promise of confidentiality to the submitter is binding. "It will obviously not be enough for the agency to assert simply that it received the file under a pledge of confidentiality to the one who supplied it. Undertakings of that nature can not, in and of themselves, override the Act." Ackerly v. Ley, 420 F.2d 1336, 1339 n.3 (D.C. Cir. 1969); accord, Petkas v. Staats, 501 F.2d 887, 889 (D.C. Cir. 1974).

89. National Parks \& Conservation Ass'n v. Morton, 498 F.2d 765, 768 (D.C. Cir. 1974). 
fourth exemption.

A second argument favoring application of the Restatement definition to safety and effectiveness data is based on the fact that the FDA has endorsed this definition in the past. The preamble to the 1974 FOIA regulations states:

[T] he Restatement definition of a trade secret should remain the basic guideline for application of this exemption from the Freedom of Information Act. The Supreme Court has recently noted that the Restatement definition of a trade secret is "widely relied upon," . . . The Commissioner [of Drugs] can find no reason why it should be utilized for determining commercial damages but not for purposes of the Freedom of Information Act. ${ }^{90}$

Although the agency cannot alter the provisions of the FOIA by its own express or miphied promises of confidentiahty, ${ }^{91}$ it was clearly the intent of Congress that agency practices and the expectations of the submitter sliould be considered in determining the applicability of the fourth exemption. ${ }^{92}$ In view of the FDA's endorsement of the Restatement definition, there is clear justification for reliance on that definition by the submitter.

A third reason for applying the Restatement definition is the fact that it is the most widely used definition of a trade secret and it has been adopted by many state courts and legislatures. In the absence of any definition in the FOIA, it can be implied that Congress intended the terin to have the scope accorded to it by common use. Advocates of the narrower Consumers Union definition will argue that the Restatement definition, which evolved out of tort law dealing with breaches of trust by former employees, has no application to the FOIA. However, in view of the close conformity of the Restatement definition to the purpose of the fourth exemption, its endorsement by the FDA and its general acceptance, the court im construing the terin "trade secret" in the context of the FOIA likely would adopt the Restatement definition.

If that definition were accepted, it seems clear that safety and effectiveness data would be found to constitute a trade secret. Although some argument could be made that the data is not a method or process $^{93}$ as required under the narrower definition, ${ }^{94}$ it certainly is a "compilation of infornation." Given the requirement for subnission of the data in order to obtaim a license to market the drug, there can be no

90. 39 Fed. Reg. 44,602, 44,612 (1974).

91. See note 88 supra.

92. See note 88 supra. See National Parks \& Conservation Ass'n v. Kleppe, 547 F.2d 673 (D.C. Cir. 1976).

93. The protocol itself clearly is a method or process.

94. See text accompanying notes $165-75$ infra. 
doubt that the data is "used in one's business." Finally, considering the tens of millions of dollars generally required for the development of the data, the knowledge contained in it and the resulting license if the NDA is approved, the data clearly gives its developer "an advantage over competitors who do not know or use it," especially in the case of unpatented drugs.

The conclusion that safety and effectiveness data constitutes a trade secret is strengthened by the recognition of a helpful distinction between trade secrets and confidential commercial information. The competitive advantage associated with a technological trade secret is almost always jeopardized by any disclosure to competitors, even if the source of the data is not revealed. Confidential commercial information, on the other hand, can usually be released without any competitive harm if the source of the data is withheld. ${ }^{95}$ Thus, for example, affirmative action plans are always considered under the "confidential commercial or financial information" part of exemption 4 and not as trade secrets. ${ }^{96}$ Those plans would be of virtually no practical value to conıpetitors unless acconıpanied by inforination identifying the firm implementing such plans. This is clearly not the case with safety and effectiveness data. Publication without attribution would be as harmful as release with attribution. In eitlier case, data costing millions of dollars to compile would be available to competitors for their own drug developinent at no real cost. This would mevitably cause competitive harn. ${ }^{97}$

1. The Material Falls Within Exemption 4 and Therefore Should Not be Disclosed. Submitters seeking to protect the confidentiality of safety and effectiveness data would first argue that the agency should not be perinitted to release material exempt from the disclosure re-

95. Milgrim, Trade Secrets, in 12 Business ORganizations \& 6.02A[2], at 6-46.15 n.26.

96. See, e.g., Sears, Roebuck \& Co. v. Eckerd, 575 F.2d 1197 (7th Cir. 1978); General Dynamics Corp. v. Marshall, 572 F.2d 1211 (8th Cir. 1978), vacated and remanded, 99 S. Ct. 2024 (1979).

97. The question of the applicability of exemption 4 to safety and effectiveness data was addressed in Morgan v. FDA [1974 Transfer Binder] Food DRUG Cos. L. REP (CCH) I 41,147 (D.C. Cir. 1974). In that case, the plaintiff sought disclosure of safety and effectiveness data for certain oral contraceptives. The FDA refused to disclose this information and argued that the data fell within exemption 4. The agency was awarded summary judgment because the plaintiff failed to contest the FDA's assertion that the data was either a trade secret or confidential coinmereial information.

Here, of course, we are dealing with a situation in which the FDA is seeking to release the data, not withhold it. Because 18 U.S.C. $\$ 1905$ (1976) and 21 U.S.C. § 331(j) (1976) impose eriminal sanctions for the unlawful release of trade secrets, it is necessary to determine whether safety and effectiveness data constitutes a trade secret. The Morgan court did not find it necessary to address this issue. 
quirements of the FOIA, especially when that disclosure could cause serious competitive harm. In cases seeking to force an agency to release rather than withhold data, courts have held that exemption 4 "may be invoked [by the agency] for the benefit of the person who has provided commercial or financial information if it can be shown that public disclosure is likely to cause substantial harm to his competitive position." 98 The legislative history of the Act contains numerous indications of congressional intent to establish "workable standards for what records should and should not be open to public inspection."99

Yet, despite this concern, most courts and the subsequent legislative history agree that the FOIA exemptions are permissive ${ }^{100}$ and that an agency decision to release information can be set aside only for an abuse of administrative discretion. ${ }^{101}$ In Westinghouse Electric Corp. $v$. Schlesinger, ${ }^{102}$ the Fourth Circuit Court of Appeals, which is known for its narrow reading of the permissible scope of disclosure under the FOIA, ${ }^{103}$ stated:

So far as exempt information is concerned, the Act . . . "neither authorizes [n]or prohibits the disclosure of such information," and the disclosure of such exempt information is ordmarily discretionary with the agency. . . . [W] [Wen review of an administrative decision to disclose is sought . . . under the APA, . . . it is subject to reversal if arbitrary, capricious, an abuse of discretion "or otherwise not in accordance with law." 104

Two tests are applied by the courts in determining whether an agency has abused its discretion by releasing data that falls within an exeinption to the FOIA. If the agency's decision is to be upheld, the court inust first be assured that the decision was based upon a consideration of all relevant factors and that the reasons stated provide support for the dccision. ${ }^{105}$ In making this determination, the court inust be convinced that the agency has considered the possible harm to both the submitter of the data and the general public as a result of disclosure, as

98. National Parks \& Conservation Ass'n v. Morton, 498 F.2d 765, 770 (D.C. Cir. 1974).

99. S. Rep. No. 813, 89th Cong., 1st Sess. 5 (1965), quoted in Westinghouse Elec. Corp. v. Schlesinger, 542 F.2d 1190, 1211 (4th Cir. 1976) (emphasis added by Westinghouse court).

100. See note 53 supra and text accompanying notes 47-53 supra. The Supreme Court has recently confirmed that the exemptions are permissive. Chrysler Corp. v. Brown, 99 S. Ct. 1705 (1979).

101. See text accoinpanying notes $68-70$ supra.

102. 542 F.2d 1190 (4th Cir. 1976).

103. Compare Westinghouse with Sears, Roebuck \& Co. v. Eckard, 575 F.2d 1197 (7th Cir. 1978), General Dynamics Corp. v. Marshall, 572 F.2d 1211 (8th Cir. 1978), vacated and remanded, 99 S. Ct. 2024 (1979) and Chrysler Corp. v. Schlesinger, 565 F.2d 1172 (3d Cir. 1977), vacated and remanded sub nom. Chrysler Corp. v. Brown, 99 S. Ct. 1705 (1979).

104. 542 F.2d at 1197-98 (quoting 5 U.S.C. \& 706(2)(A) (1976)).

105. Pennzoil Co. v. FPC, 534 F.2d 627, 631 (Sth Cir. 1976). 
well as resulting benefits. The court will also want assurances from the agency that there is no alternative disclosure plan that could provide the benefits of disclosure with less harm to private and public interests. ${ }^{106}$

If the FDA, after consideration of all relevant factors and alternatives, were to promulgate regulations providing for the disclosure of safety and effectiveness data based on its conclusion that the benefits of disclosure-opening up agency decision making, curtailing unnecessary and expensive duphicative testing, and sharing of scientific expertise-outweigh possible harns such as reduced incentive for research and development of new drugs, a court would probably defer to agency expertise and would not be willing to set the regulations aside under the first abuse-of-discretion test. The task of constructing the cost-benefit calculus lies with the agency and not the courts. If the FDA's evaluation of the impact of disclosure takes into account all relevant factors, it would be quite difficult for a judge to find that calculus incorrect. The instinct of a court when confronted with such a problein will almost inevitably be to defer to agency expertise. With regard to the FDA's present disclosure policy, one court noted that in proinulgating the disclosure regulations, the agency was acting in an area "which directly concerns the realm of its special expertise and administrative experience. In reviewing the merits of the case this is an important consideration." 107 The deference accorded to the FDA is probably greater than that given to other agencies because its decisions are usually based on very technical scientific analysis rather than legal or political theories and because of respect for medical decision inaking. ${ }^{108}$

The second test of whether an abuse of administrative discretion has occurred requires a determination of whether the act complained of would constitute a violation of another statute. This was inade clear in Charles River Park " $A$ ", Inc. v. Department of Housing and Urban Development: ${ }^{109}$ "[I]f the disclosure of the infornation involved here would constitute a violation of a criminal statute, it would be an abuse

106. Id. at 632 .

107. Pharmaceutical Manufacturers Ass'n v. Weinberger, 401 F. Supp. 444, 446 (D.D.C. 1975).

108. This point was vividly made by one FDA observer:

[E]very experienced food and drug lawyer will tell you that in 999 out of 1,000 cases, even the most sanguine counsel knows that he hasn't a prayer of persuading an appellate court to second-guess the FDA . . . .

It is indeed a sturdy appellate judge who is not teinpted to clutch his stomach, to recall every episode of family illness, and to react in favor of those who march under the banner of protecting the aged, lactating inothers, and infant children.

Austern, Sanctions in Silhouette: An Inquiry Into the Enforcement of the Federal Food, Drug, and Cosmetic Act, 51 CaL. L. REv. 38, 45 (1963).

109. 519 F.2d 935 (D.C. Cir. 1975). 
of discretion for an agency to ignore such a statutory mandate and release the information." 110 Thus, before the FDA can release safety and effectiveness data, it must be shown that disclosure would violate neither the Trade Secrets Act ${ }^{111}$ nor the Food, Drug and Cosmetic Act. ${ }^{12}$

\section{The Trade Secrets Act Prohibits Release. The submitters' sec-}

110. Id. at 942 .

111. 18 U.S.C. § 1905 (1976).

112. The confidentiality provision of the Food, Drug and Cosmetic Act is found at 21 U.S.C. \& 331(j) (1970).

That the FOIA should not be construed to overrule statntes prohibiting disclosnre is a concern expressed throughout the Act's legislative history. This concern is written into the Act itself, and exemption 3 states that the Act "does not apply to matters that are . . specifically exempted from disclosure by statute. . . provided that such statute (A) requires that the matters be withheld from the public in such a manner as to leave no discretion on thc issue, or (B) establishes particular criteria for withholding or refers to particular types of matters to be withheld." 5 U.S.C. § 552(b)(3) (1976) (emphasis added).

There has been disagreement whether 18 U.S.C. $\S 1905$ (1976), the Trade Secrets Act, falls within the scope of exemption 3. In FAA v. Robertson, 422 U.S. 255 (1975), the Supreme Court ruled that the exemption did cover a provision of the FAA Act that gave the agency blanket discretion to withhold information. Congress reacted to Robertson by amending exemption 3 to read as quoted above in order to narrow its scope to those statutes that require withholding of specific information. Most courts have held that exemption 3 "does not incorporate section 1905 into the FOIA in such a way as to make section 1905 broader than the fourth exemption." Charles River Park "A", Inc. v. Department of HUD, 519 F.2d 935, 941 n.7 (1975). Thus, the test for purposes of exemption 3 is whether the information falls within both exemption 4 and $\S 1905$. Id. This approach of the Charles River Park court was cited with approval by the House Committee on Government Operations in its consideration of the Government in the Sunshine Act, Pub. L. No. 94-409, 90 Stat. 1241 (1976) (codified at 5 U.S.C. $§ 552 \mathrm{~b}$ (1976) and scattered sections of 5 U.S.C.):

[I] material did not coine within the broad trade secrcts exemption contained in the Freedom of Information Act, section 1905 would not justify withholding; on the other hand, if material is within the trade secrets exemption of the Freedoin of Information Act and therefore subject to disclosure if the agency determines that disclosure is in the public interest, section 1905 inust be considered to ascertain whether the agency is forbidden from disclosing the information.

H.R. REP. No. 880, Part I, 94th Cong., 2d Sess. 23 (1976), reprinted in [1976] U.S. CODE CoNG. \& AD. News 2183, 2205; see National Parks \& Conservation Ass'n v. Kleppe, 547 F.2d 673, 686-87 (D.C. Cir. 1976). One court noted that the legislativc history on the 1976 amendinent "indicate[s] that one of the purposes . . . is to assure that $\S 1905$ is not considered to be within the ambit of exemption (b)(3)." Metropolitan Life Ins. Co. v. Usery, 426 F. Supp. 150, 158 n.15 (D.D.C. 1976). Another court recently declared that " $\$ 1905$ does not qualify as an exemption 3 statute." Nationwide Mut. Ins. Co. v. Friedınan, 451 F. Supp. 736, 742 (D. Md. 1978).

Thus, it remains to be determined ouly that safety and effectiveness data falls within the scope of section 1905. This question is addressed in the next section of the Comment.

As for 21 U.S.C. $\S 331(j)$ (1976), the confidentiality provision of the Food, Drug and Cosmetic Act, there is no question that it is specific and narrow enough to qualify as an exemption 3 statute. Thus, cven if safety and effectiveness data is found not to be exempt from the FOIA through exeinption 4, it would be exeinpt froin the Act through exemption 3 , if safety and effectiveness data is protected by section $331(\mathrm{j})$. That question is addressed in the text acconpanying notes 165-75 infra. 
ond line of defense would be the argument that release of safety and effectiveness data would violate the Trade Secrets Act, ${ }^{113} 18$ U.S.C. $\S 1905$, which prohibits any disclosure of protected material (relating to trade secrets or confidential statistical data) that is "not authorized by law."

The first question to be addressed is whether section 1905 and exemption 4 are coextensive. In the view of the FDA, the scope of the two sections is practically identical:

The Commissioner [of Drugs] concludes that it is not feasible or practical to determine the differences, if any, between the confidentiality provisions in 18 U.S.C. [\$] $1905 \ldots$ and in the Freedom of Information Act. If there are any differences, they are extremely subtle and small. Accordingly, the Commissioner intends . . . to regard the coverage of these provisions as identical. ${ }^{114}$

Several courts have also found the two provisions to be identical. They have done so, however, by misreading both precedent and legislative history. In Westinghouse Electric Corp. v. Schlesinger, ${ }^{115}$ the court stated that

it has been uniformly lield that the scope of $\S 1905$ and Exemption 4 of the FOIA are . . the 'same' or . . . "co-extensive." Accordingly, Inaterial qualifying for exemption under (b)(4) falls within the inaterial, disclosure of which is prohibited under \& 1905. And this was the specific holding in Charles River Park . . . 116

Yet, the Charles River Park court held only that "if the disclosure

113. 18 U.S.C. $§ 1905$ (1976) provides:

Whoever, being an officer or employee of the United States or of any department or agency thereof, publishes, divulges, discloses, or makes known in any manner or to any extent not authorized by law any information coming to him in the course of his employment or official duties or by reason of any exammation or investigation made by, or return, report or record made to or filed with, such department or agency or officer or employee, thereof, which information concerns or relates to the trade secrets, processes, operations, style of work, or apparatus, or to the identity, confidential statistical data, amount or source of any income, profits, losses or expenditures of any person, firm, partnership, corporation, or association; or permits any income return or copy thereof or any book containimg any abstract or particulars thereof to be seen or examined by any person except as provided by law; shall be fined not more than $\$ 1,000$ or imprisoned not more than one year, or both; and slall be removed from office or employment.

114. 39 Fed. Reg. 44,602, 44,612 (1974). In a suit challenging the agency's procedure for notification of submitters when there is a FOIA request for their information, the FDA agreed that the provisions of $\$ 1905$ and exemption 4 are "for the purposes of this suit, the same." Pharmaceutical Mfrs. Ass'n v. Weimberger, 401 F. Supp. 444, 446 (D.D.C. 1975).

This reasoning was criticized in Pendergast, Problems and Opportunities Under the Public Information Regulations of the FDA, 30 FOOD, DRUG \& COSM. L.J. 326, 334 n.35: "The FDA cites no authority for this conclusion and it could lead to trouble. The distinction may be, as the FDA says, 'subtle,' but subtle differences can cause major arguments."

The Supreme Court did not address this question in Chrysler Corp. v. Brown, 99 S. Ct. 1705 (1979).

115. 542 F.2d 1190 (4th Cir. 1976), cert. denied, 431 U.S. 924 (1977).

116. 542 F.2d at 1204 n.38 (citations omitted). 
of the information involved here would constitute a violation of a criminal statute, it would be an abuse of discretion for an agency to ignore such a statutory mandate and release the information." 117 In fact, Charles River Park, in a footnote to which the Westinghouse court refers, clearly indicates that section 1905 and exemption 4 are not of the saine scope: "Since only the FOIA's fourth exemption deals with matters covered by section 1905, consideration of section 1905 in FOIA cases is appropriate only when the information falls both within the fourth exemption and under section 1905."118 This statement implies that the two provisions are not identical in scope. If they were, the court probably would have simply stated that the only inquiry must be whether the release is "authorized by law." 119

Similarly, the court in Westchester General Hospital, Inc. v. Department of Health, Education and Welfare ${ }^{120}$ found that section 1905 and exeinption 4 "are equivalent in scope." 121 This conclusion, like that in Westinghouse, was based on Charles River Park, but the court went on to quote legislative history in defense of its finding. It claimed that the following stateinent from the House report on the 1976 amendments to the FOIA shows the congruence of the two provisions: "[I]f material did not coine within the broad trade secrets exemption contained in the Freedoin of Information Act, section 1905 would not justify [nondisclosure] . . . ."122 However, this passage only indicates that section 1905 is not broader than exemption 4. It clearly leaves open the possibility that data can be exeinpt from the FOIA through exemption 4 and still be disclosed, at the agency's discretion, in situations where section 1905 does not apply. The House report relied upon in Westchester General Hospital goes on to make this point. Immediately after the section quoted by the court, the report states that "if material is within the trade secrets exeinption ... and therefore subject to disclosure if the agency determines that disclosure is in the public interest, section 1905 inust be considered to ascertain whether the agency is forbidden from disclosing the information." 123 Again, were the provisions identical im scope, Congress could have stated inore precisely that the only question

117. 519 F.2d at 942 (emphasis added).

118. Id. at $942 \mathrm{n} .7$ (emphasis added).

119. See text accompanying notes 148-64 infra.

120. 434 F. Supp. 435 (M.D. Fla. 1977).

121. Id. at 439 .

122. Id. (quoting H.R. REP. No. 880, Part I, 94th Cong., 2d Sess. 23, reprinted in [1976] U.S. CODE CoNG. \& AD. News 2183, 2205).

I23. H.R. REP. No. 880, Part I, 94th Cong., 2d Sess. 23, reprinted in [1976] U.S. CODE CONG. \& AD. NEws 2183, 2205, quoted in Nationwide Mut. Ins. Co. v. Friedman, 451 F. Supp. 736, 743 (D. Md. 1978). 
was whether the disclosure was authorized.

The contention that exemption 4 is broader than section 1905 might, at first glance, seem erroneous. Whereas the former protects trade secrets and certain privileged commercial or financial information, the release of which would cause serious competitive harm, ${ }^{124}$ the latter seemingly protects anything that "concerns or relates to ... trade secrets," as well as a hist of other kinds of information. ${ }^{125}$ This dilemma is resolved by examining the historical roots of the present section $1905,{ }^{126}$ enacted as part of the 1948 codification of the federal criminal code. The new section combined three preexisting laws: first, an incoine tax statute prohibitimg disclosure of any data (imcluding the operations of any busmess) gathered im the course of an IRS imvestigation or found in tax returns; ${ }^{127}$ second, a tariff commission statute forbidding disclosure of "trade secrets . . . embraced in any exammation or investigation" by the Tariff Commission; 128 and, finally, a statute directing the Commerce Department not to disclose "statistical information furnished in confidence to the Bureau of Foreign and Domestic

124. National Parks \& Conservation Ass'n v: Morton, 498 F.2d 765 (D.C. Cir. 1974).

125. See note 113 supra and accompanying text.

126. See Clement 607-13; Chrysler Corp. v. Brown, 99 S. Ct. 1705 (1979).

127. Act of Aug. 27,1894 , ch. $349, \S 34,28$ Stat. 509 (current version at 18 U.S.C. $\S 1905$ (1976)) provided:

[I]t shall be unlawful for any collector, deputy collector, agent, clerk or other officer or employe of the United States to divulge or to make known in any manner whatever not provided by law to any person in the operations, style of work or apparatus of any manufacturer or producer visited by him in the discharge of his official duties, or the amount or source of income, profits, losses, expenditures, or any particular thereof, set forth or disclosed in any incoine return...., or to permit any income return or copy thereof or any book contaiming any abstract or particulars thereof, to be seen or examined by any person except as provided by law; and it shall be unlawful for any person to print or publish in any inanner whatever not provided by law any income, return, or any part thereof or source of income, profits, losses, or expenditures appearing in any income return; and any offense against the foregoing provision shall be a misdemeanor and be punished by a fine not exceeding one-thousand dollars or by imprisonment not exceeding one year, or both, at the discretion of the court; and if the offender be an officer or employee of the United States he shall be dismissed from office and be incapable thereafter of holding any office nnder the Government.

128. Act of June 17, 1930, ch. $497, \S 335,46$ Stat. 590 (current verion at 18 U.S.C. $\S 1905$ (1976)) provided:

It shall be unlawful for any member of the commission, or for any einployee, agent, or clerk of the commission, or any other officer or einployee of the United States, to divulge, or to make known in any inanner whatever not provided for by law, to any person, the trade secrets or processes of any person, firm, copartnership, corporation, or association ennbraced in any examination or investigation conducted by the commission, or by order of the commission, or by order of any member thereof. Any offense against the provisions of this section shall be a misdemeanor and be pumished by a fine not exceeding $\$ 1,000$, or by inprisonment not exceeding one year, or both, in the discretion of the court, and such offender shall also be dismissed from office or discharged from employment. 
Commerce."129 Much of the original language of these statutes has been incorporated into section 1905, but, "taken literally, the consohdated version . . . lias a treinendously broader scope than the original three statutes." 130

Nevertheless, according to the legislative history of the codification statute, it was not the intent of Congress "to create any substantive changes in existing criminal statutes but merely to rearrange and consolidate thein." 131 The Senate report states that the purpose of the 1948 revision was to inake it "easy to find the criminal statutes because of the arrangeinent, numbering, and classification. The original intent of Congress is preserved."132 In addition, the Reviser's Notes in the House report indicate that, with respect to the three statutes coinbined in section 1905, only "[1n]inor changes were made in translations and phraseology."133

The Supreme Court has recognized that the 1948 codification of the criminal code was not designed to bring about substantive change in the criminal laws. In United States $v$. Cook, ${ }^{134}$ the Court examined the effect of codification on an einbezzleinent statute. The Court stated: "The general purpose of the new Code was to 'codify and revise . . . . The original intent of Congress is preserved,' . . . and . . . the reviser's note ... disclosed no intention of making any change in the substantive content or the coverage of the law." 135 As one cominentator has argued, "[t]he Cook decision supports the proposition that the 1948 codification statute should not be interpreted as having created any substantive change in the meaning of the predecessor nondisclosure statutes .... [T] he [new] statute should be interpreted according to the legislative intent underlying the original statute[s]."136

Thus, it appears that the scope of section 1905 is much narrower

129. Act of Jan. 27, 1938, ch. $11, \S 1,52$ Stat. 8 (current version at 18 U.S.C. $\$ 1905$ (1976)) provided:

[A]ny statistical information furnished in confidence to the Bureau of Foreign and Donestic Commerce by individuals, corporations, and firms shall be held to be confidential, and shall be used only for the statistical purpose for which it is supplied. The Director of the Bureau of Foreign and Domestic Commerce shall not permit anyone other than the sworn einployees of the Bureau to examine such individual reports, nor shall he permit any statistics of doinestic commerce to be published in such manner as to reveal the identity of the individual, corporation, or firm furnishing such data.

130. Clement 614 (footnote omitted).

131. Id.

132. S. Rep. No. 1620, 80th Cong., 2d Sess. 1 (1948) (remarks of Sen. Wiley), quoted in Clement 614 .

133. H.R. Rep. No. 304, 80th Cong., 1st Sess. A128, quoted in Clement 614 n.116.

134. 384 U.S. 257 (1966).

135. Id. at 260 (quoting S. Rep. No. 1620, 80th Cong., 2d Sess. 1 (1948)); see Clement 615.

136. Clement 615-16 (footnote omitted). This article has been cited with approval in recent cases. See, e.g., Sears, Roebuck \& Co. v. Eckerd, 575 F.2d 1197, 1200 n.9 (7th Cir. 1978). 
than its language would indicate. It is, as the legislative history of the 1976 FOIA ainendinent recognizes, ${ }^{137}$ much narrower than the FOIA's fourth exemption. This conclusion is corroborated by the very nature of the provisions; the fourth exemption merely creates an area for the exercise of administrative discretion, while section 1905 is a criminal statute that must be construed narrowly. Should this historical view of the scope of section 1905 be accepted, it clearly would not prohibit disclosure of safety and effectiveness data, for that data is not collected in the course of tax or tariff activity or subinitted to the Bureau of Foreign or Domestic Commerce.

Even if this historical analysis is rejected, it does not necessarily follow that disclosure of safety and effectiveness data by the FDA would be prohibited by section 1905 . One reason is that it is not clear whether section 1905 was intended to limit an agency's authority to disclose information. Perhaps it was the intent of Congress not to restrict agency action, but siniply to penalize unauthorized disclosure by individual employees. If so, FDA disclosure of safety and effectiveness data in accordance with properly promulgated regulations would not constitute a violation of section 1905. ${ }^{138}$ There is no definitive answer to what the Seventh Circuit Court of Appeals in Sears, Roebuck and Co. v. Eckerd" ${ }^{139}$ called this "difficult and as yet unresolved question." 140 Yet, the Sears court offered two reasons for viewing the provision as restricting unauthorized individual acts and not agency decision making. First, the legislative history of the income tax statute that was codified as section $1905^{141}$ indicates that one of the primary concerns of Congress was the untrustworthiness of tax officials. That statute, originally enacted in $1864,{ }^{142}$ was modified by the Tariff Act of $1894,{ }^{143}$ another part of which required corporations to maintain financial records for inspection by tax officials. ${ }^{144}$ In the context of the latter section, Senator Aldrich, in a statement partially quoted by the Sears court, ${ }^{145}$ emphasized the need to constram individual agents: "The secrets of the business of every corporation in the Uinted States are practically to be made known to competitors or made public by this

137. See text accompanying notes 122-23 supra.

138. See Sears, Roebuck \& Co. v. Eckerd, 575 F.2d 1197, 1201 (7th Cir. 1978). The Supreme Court has seemingly rejected this argument. Chrysler Corp. v. Brown, 99 S. Ct. 1705 (1979).

139. 575 F.2d 1197 (7th Cir. 1978).

140. Id. at 1201 .

141. See note 127 supra.

142. Revenue Act of 1864, ch. 173, $\$ 38,13$ Stat. 223.

143. Ch. 349, § 34, 28 Stat. 509.

144. Id. $\S \S 35-36$.

145. 575 F.2d at 1201 . 
provision. ... [These secrets] are to be turned over to the tender mercies of poorly paid revenue agents." 146 Second, the Sears court noted that there are no provisions for penalizing or restraining the agency. "Even if the legislative history were unclear," the court reasoned, "limitimg the statute's focus to actions by agency employees seems more consistent with the statutory scheme because the enforcement mechanisin of the statute provides only penalties for guilty individuals and offers no restraint on agency action."147

A second reason why the FDA's disclosure of safety and effectiveness data would not necessarily be prohibited by section 1905 is that, regardless of the section's focus, it does not absolutely prohibit disclosure of information that coines within its scope, but merely precludes disclosures that are "not authorized by law." 148 Clearly, the FOIA cannot provide the necessary authorization for the hypothetical disclosure regulations allowing FDA release of safcty and effectiveness data because the Act "does not apply" to material that falls within the FOIA's fourth exemption. But, anticipating that problem, it was hypothesized that the regulations were promulgated under section $301^{149}$ as well. Thus, the question posed is whether regulations under section 301 would be regarded as "authorization by law" for the purpose of avoiding the prohibitions of section $1905 .{ }^{150}$

In authorizing agency regulations for "the custody, use, and preservation of its records, papers, and property,"151 section 301 makes no reference to the permissible scope of disclosure of data held by an agency. In 1958, because of concern that agencies were using this general housekeeping provision as authority to withhold information from the public, ${ }^{152}$ the statute was amended to imclude a second sentence: "This section does not authorize withholding information from the public or limiting the availability of records to the public." 153 Another amendment that would have added "nor shall this section be construed as requiring the givmg of information or the making of records avail-

146. 26 CONG. REC. 6893 (1894), quoted in Clement 610 n.100.

147. 575 F.2d at 1201. But see Chrysler Corp. v. Brown, 99 S. Ct. at 1716.

148. See note 113 supra and accompanying text.

149. 5 U.S.C. $\$ 301$ (1976).

150. See text accompanymg notes $44-50$ supra. The Supreme Court has just ruled that $\S 301$ "was not intended to provide authority for limiting the scope of $\S 1905$. Chrysler v. Brown, 99 S. Ct. at 1721-22.

151. 5 U.S.C. $\$ 301$ (1976).

152. "It appears that this section has been used too often by too many Government departments, agencies, and officials as an excuse for withholding information from the general public." 104 CONG. REC. 6548 (1958) (statement of Rep. Brown).

153. Pub. L. No. $85-619,72$ Stat. 547 (1958) (codified at 5 U.S.C. $\$ 301$ (1976)). 
able" was rejected. ${ }^{154}$

The legislative debates on the 1958 amendment shed no light on whether regulations under section 301 can authorize release of data covered by section 1905 . The chief proponent of the amendment, Representative Moss, stated that the amendment "does not affect the confidential status of mformation given to the Government and carefully detailed in . . . section 1905." "155 Another supporter said that "it would still be a violation of law for any agency of Government or any Government official to make public any of the records for which secrecy is provided by any of some 78 separate statutes." 156 Thus, the 1958 amendment was not intended to change government policy. "It merely defines the intent of the Congress which, in 1789, first voted this housekeeping authority. . . . It says to the departments of Government if you desire to withhold the information from anyone, including the Congress, then seek specific authority." 157 Unfortunately, the question whether section 1905 , which specifically states that disclosures that are authorized by law are permissible, was subject to section 301 regulations was never addrcssed.

Not surprisingly, the federal circuit courts are in conflict over this issue. In Charles River Park, the D.C. Circuit held that "[s]ection 301 does not authorize regulations limiting the scope of section 1905."158 This finding was based on the fact that the 1958 amendment was not intended to affect section 1905. ${ }^{159}$ Yet this leaves unresolved the question whuther the pre-1958 housekeeping provision would authorize such regulations. One commentator has argued that "past interpretations of section 1905 and other similar nondisclosure statutes imply that agency regulations constitute one form of law capable of authorizing disclosure within the ineaning of section 1905."160 This approach was accepted by the Third Circuit, and in Chrysler Corp. v. Schlesinger ${ }^{161}$ the court wrote:

We have been referred to no legislative history suggesting that $\S 1905$, a 1948 codification of a group of statutes applicable to specific agencies, was intended to limit the longstanding rulemaking au-

154. 104 CoNG. Rec. 6567-69 (1958).

155. Id. 6550.

156. Id. 6548 (remarks of Rep. Brown).

157. Id. 6550 (remarks of Rep. Moss).

158. 519 F.2d at $942-43$.

159. See text accompanying note 155 supra.

160. Clement $618-19$ (footnote omitted). This commentator notes that "as early as 1864 administrative orders issued pursuant to $\S 1905$ 's predecessor income tax nondisclosure statute authorized and restricted disclosure of tax-related information." Id. 619 n. 136.

161. 565 F.2d 1172 (3d Cir. 1977), vacated amd remanded sub nom. Chrysler Corp. v. Brown, 99 S. Ct. 1705 (1979). 
thority under the 1874 codification of the housekeeping statute . . . . Congressman Moss only stated that the amendment would not affect the confidential status of information covered by $\S 1905$. Such an interpretation of the 1958 amendment is totally at odds with its central purpose-the elimination of governmental secrecy-as it would transmogrify $\S 1905$ into a weapon for those parties who advocate government secrecy. Thus . . . $\$ 301$ is a separate source of agency authority for the promulgation of disclosure regulations and . . . disclosures pursuant to such regulations are authorized by law and immune from the prohibitions of $\S 1905 .^{162}$

In Sears, Roebuck \& Co. v. Eckerd, ${ }^{163}$ the Seventh Circuit specifically concurred in this view. The Supreme Court, however, rejected this analysis in Chrysler Corp. v. Brown. ${ }^{164}$

The foregoing discussion indicates that it would be quite difficult for the submitters of safety and effectiveness data to prevail on the contention that the Trade Secrets Act prevents FDA disclosure of that data. They would have to convince a court, first, that the proper scope of section 1905 wouid encompass all inatters relating to trade secrets and not just those protected im the statutes which were incorporated into the 1948 codification; second, that section 1905 is addressed to disclosure by official agency action as well as unauthorized acts of individual einployees; and, finally, that regulations properly promulgated under section 301 would not constitute "authorization by law" for purposes of section 1905. The Supreme Court has recently given the submitters ammunition on the last two points. The first question, however, remains open.

\section{The Confidentiality Provision of the Food, Drug and Cosmetic} Act Prohibits Release. The submitters' third line of arguinent would be that disclosure of safety and effectiveness data is prohibited by the confidentiality provision of the Food, Drug and Cosmetic Act, section 331(j), which prohibits "[t]he using by any person to his own advantage, or revealing, other than to the Secretary or officers or employees of the Department [of HEW], or to the courts when relevant im any judicial proceeding under this chapter, any information . . . concerning any inethod or process which as a trade secret is entitled to protection."165 The scope of section 331(j) has not been clearly delineated by the courts, and the legislative history is quite anbiguous on this matter.

On its face, the statute does not protect all trade secrets, but only those methods or processes that qualify as trade secrets. However,

162. 565 F.2d at 1187 (footnotes omitted).

163. 575 F.2d 1197 (7th Cir. 1978).

164. 99 S. Ct. $1705,1722-23$ (1979).

165. 21 U.S.C. § 331(j) (1976). 
neither Congress nor the FDA seems to have consistently adhered to this view. In the 1962 revision of the Food, Drug and Cosmetic Act, the House of Representatives passed a provision that would have expanded the scope of section $331(j)$ to cover all trade secrets acquired by the FDA. ${ }^{166}$ The Senate, fearing that such a provision would inhibit FDA efforts to warn the public regarding potential dangers, rejected that provision. ${ }^{167}$ This change was not mcluded in the final version of the Act, but the conference report does contain a statement indicative of a congressional belief that section 331(j) already encoinpassed all trade secrets:

It is expected, of course, that since the Congress is not making the law nore restrictive on this matter, the FDA will not make its interpretation and administration of [the] section . . . more restrictive. Congress and the public deserve to have access to information in the Food and Drug Administration which is not of the nature of a trade secret and is in the public interest. ${ }^{168}$

At that time, the FDA also inaintained that the protection of section 331(j) should not be limited to inethods and processes. In fact, the FDA's position, as reflected in an in-house ineinorandum in 1960, was clearly overbroad:

[The FDA] has uniformly treated all material submitted to it in new drug applications as being confidential whether or not 'trade secrets' were involved .... [This relieves the FDA] of the risk of having to determine whether or not every particular piece of information is or is not a 'trade secret' . . . . ${ }^{169}$

In the 1974 Public Information Regulations, the FDA recognized the need for a soinewhat narrower construction of the scope of section 331(j), but still insisted that all trade secrets, not just inethods and processes, were protected. ${ }^{170}$ It seems, however, that the FDA was not very certain of this stance. It fell back upon "the consistent administrative interpretation that this statutory provision can encompass animal and liuman [safety and effectiveness] data"171 and concluded that because of that "longstanding interpretation," release of safety and effec-

166. H.R. REP. No. 2464, 87th Cong., 2d Sess. 15 (1962); INTERIM REPORT 9.

167. CONF. Rep. No. 2526, 87th Cong., 2d Sess. 26, reprinted in [1962] U.S. CODE CONG. \& AD. NEwS 2927, 2935; INTERIM REPORT 9.

168. Hearings on Interagency Coordination in Drug Research and Regulation Before the Subcomm. on Reorganization and International Organizations of the Senate Comm. on Government Operations, 88th Cong., 1st Sess., pt. 3, at 1191 (remarks of Sen. Kefauver), quoted in INTERIM REPORT 10.

169. Memorandum from William F. Goodrich, Assistant General Counsel, FDA, to Bill V. McFarland, Assistant Director, Division of Federal-State Relations, FDA (1960), quoted in INTERIM REPORT 8.

170. 39 Fed. Reg. 44,612 (1974).

171. Id. 44,602 . 
tiveness data would be improper. ${ }^{172}$ The agency was apparently unsure of the validity of this argument and continued, "regardless of the scope of section 331(j) . . . the provisions of 18 U.S.C. 1905 and the trade secrets exemption of the Freedom of Information Act are clearly applicable to such data." 173 It has been shown, however, that these statutes do not necessarily preclude disclosure.

Clearly, the nondisclosure requirement of section 331(j), which covers any "method or process which as a trade secret is entitled to protection," would apply to the test protocols or the designs for safety and effectiveness experiments. These protocols are certainly methods or processes and would constitute trade secrets to the extent that the testing practices are not generally known in the industry. The fact that certain companies are able to obtain FDA approval for new drugs inuch more quickly than otleers indicates that innovative testing techniques are of great commercial value and should qualify as trade secrets. However, it is not clear that this protection should extend to the scientific findings resulting from the safety and effectiveness trials. As Theodore Cooper, then Assistant Secretary of HEW for Health, stated to Congress:

[Safety and effectiveness data in new drug applications] should not be regarded as trade secrets or proprietary information. The Department believes that the concept that animal and human data on safety and effectiveness of a drug are proprietary information belonging to a single manufacturer sliould not be supported because of the enormous social and economic costs of such a policy. This concept creates an impression of secrecy and generates unnecessary and duplicative human research. Consideration of safety and effectiveness data as trade secrets appears to serve a competitive and economic purpose for which the patent laws are more properly intended. We believe, therefore, that scientific data relating to safety and effectiveness of a drug slould be in the public domain, while, at the same time, we contimue to support the view that manufacturing metlods and processes are properly considered as trade secrets. ${ }^{174}$

Thus, here too, the validity of the submitters' argument that the law forbids disclosure of safety and effectiveness data is uncertain. However, given the breadth of past constructions of section 331(j) and the apparent congressional recognition in 1962 that the confidentiality of all trade secrets was to be protected by the FDA, this argument for the protection of safety and effectiveness data may be successful.

172. Id. 44,634-35.

173. Id. 44,635 .

174. Drug Safety Amendments of 1976: Hearings on H.R. 12391 Before the Subcomm. on Public Health and Environment of the House Comm. on Interstate and Foreign Commerce, 94th Cong., 2d Sess. 12-13 (1976), quoted in INTERIM REPORT 24-25. 
In reviewing the legal theories available to the submitters of safety and effectiveness data, one must conclude that their arsenal against disclosure of the data under properly promulgated regulations is uncertain. The FOIA, though not authorizing release, would not prevent it. It is questionable whether the protection of the Trade Secrets Act would be sufficient to prohibit disclosure under properly promulgated regulations. Finally, it is not clear that safety and effectiveness data would constitute a "method or process" and thus qualify as a trade secret protected under the Food, Drug and Cosmetic Act. Therefore, if the FDA were to conclude that release of this information would be in the public interest and would not place undue burdens on the drug industry, a court might very well recognize the agency's expertise and refuse to find an abuse of discretion. The courts are generally loath to substitute their judgment for agency expertise in this area. ${ }^{175}$

\section{The Policy Implications of Release of Safety and EFFECTIVENESS DATA}

Although the FDA might well be able to release safety and effectiveness data submitted with new drug applications under present law, it does not necessarily follow that such disclosure would be sound on public policy grounds. In addition to its uncertainty as to the legality of disclosure, the FDA has consistently refused to authorize full disclosure of the data due to its belief that such a decision should be left to Congress. ${ }^{176}$ That question is now before Congress as part of the Drug Regulation Reform Bill. ${ }^{177}$ The remainder of this Comment will show that the disclosure rules in the proposed legislation are likely to have a substantial adverse impact on research and development of new drugs and exacerbate the problem of drug lag, and an alternative scheme for disclosure of the data will be presented. As a preliminary matter, how-

175. See note 108 supra and text accompanying notes 107-08 supra.

176. 39 Fed. Reg. 44,602, 44,634 (1974).

177. S. 2755 and H.R. 11611, 95th Cong., $2 d$ Sess. (1978). These bills were reintroduced in the present Congress, S. 1045 and H.R. 4258, 96th Cong., 1st Sess. (1979). Identical versions of the bill drafted by the Carter Administration were originally filed in each house on March 16, 1978. The Senate bill, S. 2755, was referred to the Subcommittee on Health of the Committee on Human Resources; the House bill, H.R. 11611, was referred to the Subcommittee on Public Health and the Environment of the Committee on Interstate and Foreign Commerce. The bills were introduced by the chairmen of those subcommittees, Senator Kennedy and Representative Rogers. The bill was drafted by the FDA after conducting extensive public hearings, and it represents an effort to enact a compromise bill. The bill contains some reforms for which industry has lobbied heavily, such as easier and cheaper procedures to obtain a license to market new drugs. 36 CoNG. Q. 689-93 (1978). Yet, the provisions in the bill allowing for the release of safety and effectiveness data have annoyed the industry to such an extent that the president of the Pharmaceutical Manufacturers Association has remarked, "If we had to say the administration bill or none at all, we would say none." Id. 689. 
ever, a brief overview of the economics of research and development in the drug industry will be helpful.

\section{A. The Economics of Pharmaceutical Research.}

In few other major industries is research and developinent as significant as it is in the drug industry. It is important to both the individual companies and the public. The American pharmaceutical industry is the inost prolific source of new drugs in the world. Between 1963 and 1970 , for example, over $80 \%$ of the new drugs introduced originated from doinestic drug research. ${ }^{178}$ The price of that origmality, however, is high. It now costs an average of $\$ 50$ million and takes eight to ten years to develop and obtain approval to inarket a new drug. ${ }^{179}$

Studies of pharmaceutical research einploy a model that divides drug companies into two groups: research intensive and non-research intensive. ${ }^{180}$ The FDA's own study of the effect of the release of safety and effectiveness data uses the criterion of a $\$ 10$ million expenditure for research and developinent in 1975 as the classifying factor. ${ }^{181}$ The studies have also shown that a company's retail sales provide a good indication of the amount of money a firm will spend on research and developinent. It was found that research-intensive firms spend approximately $8-10 \%$ of their retail sales on research and developinent, while non-research-intensive firms spend only 4-5\% of their retail sales in this area. ${ }^{182}$ But because the research-intensive firms tend to be the larger coinpanies, the difference in the amount of money spent by the two groups is inuch more dramatic than the percentages might indicate. The average research-intensive firm devoted nearly $\$ 37.5$ million to global research and development in 1975, while non-research-intensive firms spent an average of only $\$ 2.9$ million. ${ }^{183}$ Thus, the twenty-five research-intensive firms in the FDA study spent $93 \%$ of the research dollar, while the twenty-four non-research-intensive firms spent only 7\%. While this indicates that research and developinent is concentrated in the larger companies, it does not tell the whole story. Other studies have shown that research output, neasured in terms of the "new chemical entities" (NCEs) inarketed, is even inore concentrated. Froin 1957 to 1961 , the four most produtive research firms provided $46.2 \%$ of the

178. Pracon Study 14.

179. Testimony of Henry Grabowski, Professor of Economics, Duke University, Before the Subcomm. on Public Health and Environment of the House Comm. on Interstate and Foreign Commerce, H.R. 11611, 95th Cong., 2d Sess., June 20, 1978.

180. Both the Pracon Study and Dworkin apply this analysis.

181. Dworkin 5.

182. Id. 7; Pracon Study 61.

183. Dworkin 5. 
innovational output; for the years 1967 through 1971 that figure was $61 \% .{ }^{184}$ Given this concentration, it is clear that smaller companies are finding it less productive to invest substantial sums in research and development.

A related problein is the marked decrease in the number of new products discovered. Despite the fact that research, in constant dollars, grew by $56 \%$ between 1965 and 1974, the number of new products actually developed declined by $26 \%{ }^{185}$ There are several possible explanations for this decline in the productivity of research. Among them are higher costs due to increased regulation by the 1962 amendments to the Food, Drug and Cosmetic Act, exhaustion of profitable research opportunities, and plain bad luck. Thus, it is not surprising to note that financial analysts have questioned the adequacy of the return on investnients in drug research. ${ }^{186}$ As one study noted, "[t]hose few firms which continue to operate large and expensive $\mathrm{R} \& \mathrm{D}$ programs inust be able to deinonstrate the viability of the research-intensive strategy in an increasingly negative environment. Otherwise inanagement will have little alternative but to cut back on such spending in favor of more productive investments." 187 To the extent that research output is related to research input, this would result in even fewer new drugs.

Another problein in the area of new drugs is the "drug lag." This tern refers to the interval between the time when drugs are marketed somewhere in the world-and the time when they are inarketed in the United States. One study has noted that of all drugs available in both the United States and the United Kingdoin by 1971, two-thirds were available first in the United Kingdon. ${ }^{188}$ This delay in the introduction of new drugs has been one of the inajor criticisms leveled at the FDA. It is only in the context of these problems-declining return on investment in research and development and drug lag-that the policy of disclosing safety and effectiveness data can be evaluated.

\section{B. The Disclosure Policy of the Proposed Legislation.}

The disclosure provisions of the proposed legislation ${ }^{189}$ represent a

184. Pracon Study 32 (using data from Grabowski \& Verron, Consumer Protection Regulation in Ethical Drugs, AMER. ECON. Rev. (Feb. 1977)).

185. Pracon Study 30.

186. See id. $37-42$.

187. Id. 39.

188. H. Grabowski, Drug Regulation and InNovation 32 (1976) (taking data from Wardell, Introduction of New Therapeutic Drugs in the United States and Great Britain: An International Comparison, I4 Clinical Pharmacology and Therapeutics 773 (1973)).

189. S. 2755 and H.R. 11611, 95th Cong., 2d Sess. (1978), reintroduced as S.1045 and H.R. 4258, 96th Cong., Ist Sess. (1979). 
marked departure from present policy. A firm seeking to market a new drug would be required to submit three reports. ${ }^{190}$ The first report would contain a summary of eacli investigation conducted "to evaluate the effectiveness of the drug entity and to assess its risk,"191 and would state the basis for the submitter's belief that the drug is safe and effective. ${ }^{192}$ This report would be made available to the public at the beginning of the FDA review process when the petition to market has been formally filed. ${ }^{193}$ The second report would include a detailed description and the protocol for each investigation and "tables, compilations, and analyses of all data and information . . . relevant to the evaluation of the effectiveness of the drug entity and the assessment of its risks."194 This report, and the third report which would contam all data compiled in the testimg, ${ }^{195}$ would be inade available to the public in two stages. When the petition is filed these reports could be disclosed to, but not copied by, persons who seek to participate in a public hearing on the petition so long as they are not connected with any competitor, disavow any commercial purpose and are willing to take security precautions to assure that no competitor will gam access to the information. ${ }^{196}$ These reports would be available to everyone, however, when the petition to market the new drug is granted. ${ }^{197}$ But, even though all competitors would have access to the data at that poimt, they could not use the data in support of their own petitions to the FDA for a period of five years. ${ }^{198}$

\section{The Arguments in Support of the Proposals.}

Advocates of release of the data have several goals in mind. First, disclosure of the data would have the effect of opening up FDA decision making. The decisions that the agency makes regardimg the marketing of new drugs play a major role in the development of overall health policy in this country, but without access to the data upon which those decisions are based, the public cannot offer any input into those decisions. Congress, through the FOIA and related legislation, has recognized the need for public awareness of the manner in which policy decisions are made. Yet, because of the secrecy surrounding evalua-

190. Id. § 111(b)(1)(B).

191. Id.

192. Id. $\S 111(\mathrm{~b})(1)(\mathrm{B})(\mathrm{i})$.

193. $I d . \S 111(\mathrm{j})(2)(\mathrm{A})$.

194. $I d . \S 111(\mathrm{~b})(\mathrm{l})(\mathrm{B})(\mathrm{ii})$.

195. Id. \& $111(\mathrm{~b})(1)(\mathrm{B})(\mathrm{iii})$.

196. Id. $\$ 111(\mathrm{j})(3)$.

197. Id. $\S 111(\mathrm{j})(2)(\mathrm{B})$.

198. Id. \& 121(b). 
tions of new drug applications, the FDA is able to avoid comphance witls the spirit of the legislation favoring open government. This secrecy is no more appropriate in scientific areas than it is in clearly pohtical ones: "[T]he public's need for information is especially great in the field of science and technology, for the growth of specialized scientific knowledge threatens to outstrip our collective ability to control its effects in our lives." 199 Opening up FDA decision making, it is suggested, will lead to a inore satisfactory resolution of the issues facing the agency; the more inforination that is available to the public, the greater the public's ability to hold the agency accountable for its decisions. In addition, makmg inforination available to outside experts will probably mean that the agency will have access to more evidence upon which to base its decisions.

A second consideration is the fact that release of the data may serve to make the agency less risk adverse. One of the major criticisms of current FDA decision making is that the pressures on agency officials are one-sided. ${ }^{200}$ Because the adverse consequences an official would encounter by appproving a less than "safe" drug are so much more severe than the problems encountered by ordering delay or further testing, regardless of the public's need for the drug, the message to FDA officials is crystal clear. The external pressures on officials thus dictate risk-adverse behavior. As forner FDA Commissioner Schmidt has noted:

[I]n all of FDA's history, I am unable to find a single instance where a Congressional committee investigated the failure of FDA to approve a new drug. But, the times when hearings have been held to criticize our approval of new drugs have been so frequent that we aren't able to count them. . . . The message of FDA staff could not be clearer. Whenever a controversy over a new drug is resolved by its approval, the Agency and the individuals involved likely will be investigated. Whenever such a drug is disapproved, no mquiry will be made. The Congressional pressure for our negative action on a new drug applications is, therefore, intense. And it seems to be increasing, as everyone is becoming a self-acclaimed expert on carcinogenesis and drug testing. ${ }^{201}$

The point is that the public might be more willing to accept some risks in new drugs than the FDA believes. By making known its willingness to accept certain risks when accompanied by certain possible corresponding benefits, the public might be able to influence the FDA to

199. Soucie v. David, 448 F.2d 1067, 1080 (D.C. Cir. 1971).

200. H. GraBowsKI, supra note 188 , at 76 .

201. Speech by Alexander Schmidt, "The FDA Today: Critics, Congress and Consumerism," National Press Club, Washington, D.C. (Oct. 29, 1974), quoted in H. GRABOWSKI, supra note 188, at 76. 
approve or at least seriously to consider drugs that it might otherwise reject.

A third argument favoring release of safety and effectiveness data is that it would decrease the amount of expensive, duplicative testing. Since the data of one experimenter would be available to all once the experimental results had been accepted, there would be no need for otliers to spend the money and time required merely to duplicate the results. The data, it is felt, is scientific knowledge that should not be hoarded. Sharing of data as proposed in the legislation, with a fiveyear ban on use of the data by another company, would protect the primary submitter's researcli mvestment while lowering the cost of research and development for everyone. This compromise thus deals with both the rapidly rising costs of research and development and the uncertainty of return on investment.

Fourth, the sharing of inforination in this protected manner would stimulate competition im the marketing of generic drugs. Once the patent on a new drug has expired, competitors, already having access to the requisite safety and effectiveness data, would encounter few, if any, barriers to entry in the market for that drug. This competition would put an effective end to the monopoly granted by the patent and would tend to lower prices for the consuming public.

Finally, it is argued that the patent system, rather than a policy of trade secrecy, should be relied upon to protect investments in pharmaceutical researcli and, therefore, the FDA slould not interfere witl that system by superimposmg on it elements of trade secrecy. While both patent and trade secret law are designed to protect imtellectual property, one commentator has pointed out the advantages of the patent system. ${ }^{202}$ Basically, patents allow for a far more efficient distribution of scarce research resources. Because patents may be filed in the early stages of research, the patent system puts all other researchers on notice that another party has appropriated the area. Therefore, it is highly unlikely that several firms will carry out substantially the same research and spend tens of millions of dollars, only to discover that the saine data has recently been submitted to the FDA by another company. Witlout the protection given by early patents, drug research would be even more costly and the return on investment even more uncertam than it is today. ${ }^{203}$

The patent system is also a much more rehable source of protection. A trade secret is only protected so long as it remains a secret, yet

202. See Kitch, supra note 20.

203. Id. 278. 
secrecy is often quite difficult to maintain. There is, of course, the risk of a leak, but other problems are also present. A research institution may find it necessary to contract with outsiders for financing or complementary technology, but such contracting poses a dilemma. "Disclosure of the secret imperils its value, yet the outsider cannot negotiate until he knows what the secret is."204 Under the patent system this problem does not arise. It is not necessary to hoard information. Simce research is spread out through early patents, there is incentive for firms engaged in research to explore new areas rather than duphicate the work of others.

\section{The Arguments Against the Proposals.}

The problein with the proposed disclosure procedure is that it does not alleviate and, in fact, is likely to aggravate two of the major probleuns facing the American pharmaceutical community-the low return on research investment and drug lag. ${ }^{205}$

The two studies sponsored by the FDA on the impact of data disclosure clearly indicate that the proposed policy will result im the loss of tens of millions of dollars each year in new drug research. This loss will occur because release of the data will allow American non-research-intensive firms and foreign firms to market drugs that will divert sales from domestic research-intensive firms. ${ }^{206}$ Even though these firms could not market "follower" drugs in the United States (because of the five-year ban on use of the data by competitors in petitions before the FDA and because of the patent protection that most new drugs have in this country), in those countries where drugs are not patentable or are given only minimal patent protection ${ }^{207}$ and where data froin foreign studies is acceptable in applications to market new drugs, ${ }^{208}$ sales that would otherwise go to the origmal developer of the drug are subject to appropriation by other firms. The vulnerability of new drugs to competition created by the disclosure policy is obviously greatest $\mathrm{m}$ those countries that require the submission of data but accept foreign data and do not provide full patent protection for new drugs. This is the case, for example, in Canada, the Netherlands, Swe-

204. Id.

205. See text accompanying notes $178-88$ supra.

206. Because research output is concentrated in the large, research-initiative firms, and because the amount of money devoted to research and development varies in direct proportion to retail sales, a loss of retail sales by the largc, research-initiative firms will mean that fewer resources will be mvested in research and development of new drugs. See text accompanying notes 178-84 supra.

207. See note 36 supra.

208. See Dworkin, Attachment B. 
den and Switzerland. ${ }^{209}$ In other countries, such as West Germany, where there is some patent protection available, ${ }^{210}$ and in nations such as Spam, where the data requirement is not strict ${ }^{211}$ (so that the unavailability of the data might not be a barrier to entry), disclosure of data will have some, but less detrimental, impact.

The Dworkin study, conducted at the FDA, attempted to quantify the loss of mvestment in American pharmaceutical research and developinent solely on the basis of the loss of sales of research-intensive companies. Sales can be lost to American non-research-intensive firms, in which case the loss to American research is equal to approximately $5 \%$ of the shifted retail sales. ${ }^{212}$ Sales may also be lost to foreign coinpetitors, $\mathrm{m}$ which case the loss to American research is the full amount the research-imtensive firm would have committed to research and developinent, about $10 \%$ of the shifted retail sales. Dworkin found that research-mtensive firms control approximately $89 \%$ of domestic sales and non-research-imtensive firms acquire an $11 \%$ share of the market for the new drug when the patent expires. Dworkin concludes that research-intensive firms will lose about $\$ 51$ million a year from the shift in domestic sales alone. In view of the fact that non-research-intensive firms devote a lower percentage of their retail sales to research and development, this will result in a decrease of approximately $\$ 2.8$ million in research and development. ${ }^{213}$,

This is, however, only the tip of the iceberg. The major loss in research funds will coine froin a loss in foreign sales by American research-intensive firms. By studying the level of patent protection available for new drugs, the need for safety and effcctiveness data to enter foreign inarkets, and the acceptability of foreign data in the nine leading foreign markets for new drugs, Dworkin calculated that one-third of all new drug sales by American firms, or $11 \%$ of their total global sales, are vuhrerable to "follower" or generic competition. ${ }^{214}$ Since American firms control about $25 \%$ of world sales, ${ }^{215}$ Dworkin assumed that foreign firms would take $75 \%$ of the sales of vulnerable drugs. Thus, it was calculated that $\$ 599$ million per year in foreign market new drug sales would shift to foreign firms. ${ }^{216}$ Non-research-intensive American firms would also be able to enter those foreign inarkets. As-

209. Id. 3.

210. $I d$.

211. Id.

212. Id. 15-18. See text accompanying notes $180-83$ supra.

213. Dworkin 15-18.

214. Dworkin 14.

215. Id. (citing U.S. Dep'T OF COMMERCE, U.S. Industrial OutLooK, 1978, at 133 (1978)).

216. Dworkin 15. 
suming that they usurp $11 \%$ of the remaining sales by American firms in foreign markets, research-intensive firms will lose an additional $\$ 20$ inillion annually in new drug sales. ${ }^{217}$ The loss in resources available for all American pharmaceutical research as the result of the sales lost to foreign compamies is approximately $\$ 53.7$ million a year; ${ }^{218}$ researchintensive firms would lose $\$ 50.1$ million im research funds while nonresearch-intensive firms would lose the remaining \$3.6 million. ${ }^{219}$ The total projected loss to research efforts by American pharmaceutical companies, which account for the vast majority of pharmaceutical discoveries, is thus $\$ 56.5$ million a year, about $4.7 \%$ of total research and developinent in 1976.220 The five-year ban on use of the data in the United States would only affect about $\$ 2$ million of that loss. ${ }^{221}$

The validity of the Dworkin study is not above suspicion. Some of the assumptions that were necessary in order to estimate the impact of the disclosure policy merit further imquiry. Dr. Dworkin assumes, for example, that American prescription sales are an accurate sample from which to predict the nature of world sales. Since American sales are equally divided between new drugs ${ }^{222}$ and old drugs, she assumes that world sales are also equally divided. It is necessary to estimate the percentage of drug sales that involve new drugs because the available statistics deal only with total sales. However, it is not clear whether the demand for drugs in this country adequately refiects the nature of drugs sold overseas. Dworkin also assumes stability in the market shares controlled by research-intensive, non-research-imtensive and foreign firms without showing any historical evidence im support of this assumption of stability. If the market share controlled by foreign companies has actually mcreased in recent years and there is reason to suspect a continuing trend, her estimates of the research loss may, in fact, be conservative. However, sensitivity analyses indicate that varying the assuniptions regarding market shares does not change the order of nragnitude of that estinnate. ${ }^{223}$ Finally, the Dworkin study does not reveal the extent to which foreign firms invest in new drug research. The nore they invest, the less the decrease in resources available for American pharmaceutical research constitutes an absolute decrease in drug

217. Id.

218. Id. 17.

219. Id.

220. Id.

221. Id. See text accompanying note 213 supra.

222. Dworkin defines a new drug as a single chemical entity or synthesis introduced in the United States for the first time. Other products are combimation drugs, duphicate products (generics) and new dosage forms. Dworkin 4.

223. Id. 17, Attachment $\mathrm{C}$. 
research. Nevertheless, the Dworkin study is extremely helpful in attempting to quantify the impact of disclosure of safety and effectiveness data on research investment.

The other major problein that disclosure of safety and effective ness data might aggravate is the drug lag. American firms will find it economically beneficial to market their new drugs overseas before making thein available in this country. If they were to market first in this country, the data would be released, and all firms would be able to attack their sales in vulnerable markets. By marketing overseas first, American companies can obtam patents in those countries where they are available and attempt to establish a predominant market position in the others. Thus, they can recover a substantial portion of their investment and begin to earn a profit before their sales become vulnerable. The longer they can delay marketing their drugs in this country, the more profitable the new drug might be. The incentive could very well be to withhold drugs froin the American market for as long as is politically and economically feasible.

This tendency will be strengthened to the extent that drug companies are wary of public unwillingness to accept the particular risks inherent in a new drug. Although the general public might very well be willing to accept certain risks, ${ }^{224}$ industry fears assaults on the drug's safety by the "Ralph Naders" of the drug world. To combat this, firms will be tempted to market their new drugs abroad for a sufficient period of time to accumulate additional evidence of the drug's safety and effectiveness. This will be especially true for new drugs produced by foreign coinpanies. These firms are not accustomed to testing their drugs as extensively as American firms because most countries do not require such elaborate testing. When faced with the obligation of making their data public if they market im the United States, many foreign firms may decide to keep their drugs out of this country. Thus, release of safety and effectiveness data could aggravate the drug lag by providing American firms witl incentives to market abroad first and by inhibiting the introduction of new drugs in the country by foreign companies.

\section{An Alternative Scheme for Disclosure of the Data.}

The primary goals of those seeking disclosure of safety and effectiveness data-opening up FDA decision making and reducing wasteful duplicative testing - are important. However, the costs that would be incurred by releasing the data under the proposed legislation are unacceptable. Thus, it is necessary to focus on how the goals of disclo-

224. See text accompanying notes 200-01 supra. 
sure may be attamed without those costs.

A three-step system of disclosure is proposed that might serve to fill this need. First, the FDA should release detailed summaries of safety and effectiveness data (analogous to the first report to be disclosed under the proposed legislation ${ }^{225}$ ) shortly before the agency $\mathrm{m}$ tends to hold hearings on the drug's safety and effectiveness. These reports should be made available to anyone, including competitors. If the FDA is seeking a meaningful contribution to the debate over whether to allow narketing of a new drug, it should not exclude evidence that could be submitted by parties having the greatest expertise in new drug research. Competitors, by their very nature, are likely to supply the most critical evaluations of another firm's experiments. If the summaries are to be made available to competitors, however, it is important that these reports not be released prematurely. Disclosure approximately one month prior to the safety and effectiveness hearing should be sufficient.

Second, the data would be absolutely protected from disclosure for a specified period of time (for exanple, five years) after approval of the new drug to allow the developer of the drug to reap a reasonable return on its imvestment. ${ }^{226}$ After that period of complete protection, a request for more or all of the data should be treated as a request for information falling under exemption 4 of the FOIA. It would, therefore, be within the discretion of the FDA to release the data. In order to do so, however, the agency would be required to show that the benefits of release of that particular data to that particular requester outweigh the likely harm to the origmal submitter. ${ }^{227}$ If disclosure would cause substantial harm to the competitive position of the original submitter, it would be very difficult for the FDA to justify release.228 However, the possibility that the data could be released might speed up therapeutic advances. If another company were on the verge of developing a breakthrough drug and that development could be advanced by the availability of safety and effectiveness data for a previously approved drug, the FDA would have the authority to release that data, except where release would cause substantial harm to the competitive position of the first drug. It nay be that such a case will arise only once every ten or twenty years. But to deny the FDA the authority to speed up

225. See text accompanying notes 191-93 supra.

226. Under current procedure, the safety and effectiveness data in applications that are rejected or withdrawn is available. 21 C.F.R. \$ 314.14(f) (1978). See INTERIM REPORT 13-14. See text accompanying note 38 supra.

227. See text accompanying notes 105-06 supra.

228. See National Parks \& Conservation Ass'n v. Morton, 498 F.2d 765, 770 (D.C. Cir. 1974). 
therapeutic advances in such a case seems inhumane.

This possibility of disclosure also creates an incentive for the original submitter of the data to seek improvements in its drug. If the drug is patented and the data is absolutely protected, the company holding the patent would not appear to have any reason to improve upon the drug. Since it has a patent for that compound, and most likely for related ones as well, ${ }^{229}$ it has no reason to invest in therapeutic improvements that would be covered by the patent. The possibility of disclosure of the data could provide the incentive necessary to encourage that coinpany to explore for improvernents.

Finally, after the patent life of a new drug has expired, the FDA should not require other coinpamies independently to develop the same type of safety and effectiveness data. Such a requireinent merely serves to protect the original drug froin competition by creatimg an additional barrier to entry and requiring expensive and scientifically unnecessary duplicative testing. This could be prevented either by releasing all of the data after the patent life or by not requiring data from those companies seeking to inarket exact duplicates of previously approved drugs. The latter alternative is the inore desirable. The FDA has already accepted that concept for drugs developed before 1962 . Rather than requiring a full NDA with all supporting test data, a firm seeking to market a duplicate of a pre-1962 drug would, under proposed regulations, ${ }^{230}$ only have to show the identity of the compounds in an " $\mathrm{Ab}$ breviated NDA" (ANDA). The agency is already considering expandimg this procedure to cover post-1962 drugs, and it should do so promptly. Such a policy would encourage generic competition and eliminate the need for wasteful duplicative testing. Since the patenting of drugs should be encouraged, ${ }^{231}$ it would not be sound policy to afford the data of unpatented drugs greater protection than that given to patented drugs. Thus, it is suggested that ten years after approval of an unpatented drug, its safety and effectiveness data should be released.

It is suggested that this three-part scheme for disclosure of safety and effectiveness data satisfies, to a large extent, the goals of those who seek full release, while minimizing the adverse impact on return on investment in new drug research and the drug lag. This process will open up FDA decision inaking by allowing access to detailed summaries of safety and effectiveness data shortly before the safety and effectiveness hearing. All of the data, including the protocols, is given absolute protection for five years. This procedure for discretionary re-

229. See text accompanying notes 19-20 supra.

230. 43 Fed. Reg. 39,126 (1978).

231. See text accompanying notes 202-04 supra. 
lease after that time could encourage development of therapeutic advances and thus lower the cost of new drug research. Expanding the use of ANDAs in conjunction with this disclosure policy should facilitate market entry for generic products and thus stimulate competition. Finally, this scheme gives an appropriate level of protection to the data of unpatented drugs. There is no reason to suspect that the proposed scheme would cause research-intensive companies to lose a substantial number of sales during the first years of a new drug's marketing when its profits inust be protected. The combimation of patents and the proposed disclosure policy should ensure an adequate return on new drug investment. Furthernore, given the absolute ban on disclosure for five years and the high level of proof necessary for release during the following years, it is unlikely that this policy would exacerbate the drug lag.

\section{CONCLUSION}

This Comment has surveyed both the legal and policy issues concerning FDA release of safety and effectiveness data. Despite the agency's insistence that it is unable to release the data, it appears that if the FDA properly promulgated disclosure regulations, such disclosure might be upheld. A change in the FDA's treatinent of this data is a major policy issue that is currently being addressed by Congress in pending legislation. It appears, however, that the disclosure rules contained in the proposed legislation would have the unacceptable effect of decreasing research and development expenditures and aggravating the drug lag. The Comment has presented an alteruative disclosure scheme that should fulfill the goals of those seeking full disclosureopening up FDA decision making and reducing wasteful duplicative testing-without those costs. 